\title{
MECHANISMS IN ENDOCRINOLOGY Bone marrow adiposity and bone, a bad romance?
}

\author{
Tareck Rharass and Stéphanie Lucas
}

Littoral Côte d'Opale University, Lille University, EA 4490, PMOI, Physiopathologie des Maladies Osseuses Inflammatoires, Lille, F-59000, France

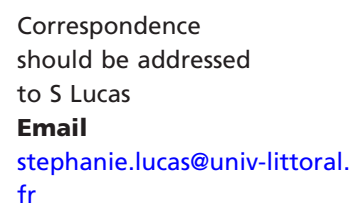

stephanie.lucas@univ-littoral. $\mathrm{fr}$

\begin{abstract}
Bone marrow adipocytes (BMA-) constitute an original and heterogeneous fat depot whose development appears interlinked with bone status throughout life. The gradual replacement of the haematopoietic tissue by BMA arises in a well-ordered way during childhood and adolescence concomitantly to bone growth and continues at a slower rate throughout the adult life. Importantly, BM adiposity quantity is found well associated with bone mineral density (BMD) loss at different skeletal sites in primary osteoporosis such as in ageing or menopause but also in secondary osteoporosis consecutive to anorexia nervosa. Since BMA and osteoblasts originate from a common mesenchymal stem cell, adipogenesis is considered as a competitive process that disrupts osteoblastogenesis. Besides, most factors secreted by bone and bone marrow cells (ligands and antagonists of the WNT/ $\beta$-catenin pathway, BMP and others) reciprocally regulate the two processes. Hormones such as oestrogens, glucocorticoids, parathyroid and growth hormones that control bone remodelling also modulate the differentiation and the activity of BMA. Actually, BMA could also contribute to bone loss through the release of paracrine factors altering osteoblast and/or osteoclast formation and function. Based on clinical and fundamental studies, this review aims at presenting and discussing these current arguments that support but also challenge the involvement of BMA in the bone mass integrity.
\end{abstract}

\section{Introduction}

The last decades have witnessed compelling evidence for fat influence on skeletal health. Among others, the two main adipokines leptin (1) and adiponectin (2) exert direct and indirect effects on bone mass. Moreover, clinical studies have drawn attention to the complex relationships between adipose tissues, their distribution and bone mineral density (BMD) (3), the main parameter used to diagnose osteoporosis and to assess fracture risk. A low BMI is a predisposing factor for fractures and, indeed, decreased BMD associated with an enhanced risk of fracture is a common comorbidity of anorexia nervosa (4). In obesity and type 2 diabetes, a higher incidence rate

\section{Invited author's profile}

Dr Stéphanie Lucas is currently Assistant Professor in the Laboratory of Pathophysiology of Inflammatory Bone Diseases (PMOI, Boulogne sur Mer), at the University of Littoral-OpaleCoast (ULCO), France. Her research focuses on characterizing the phenotype and the regulation of bone marrow adipocytes in osteoporosis and in bone defects associated with metabolic diseases through cellular, animal and clinical approaches.

(c) 2018 European Society of Endocrinology Printed in Great Britain
Published by Bioscientifica Ltd.

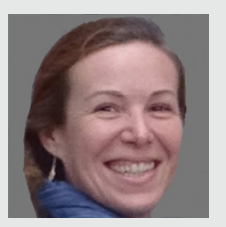


of fractures is reported despite normal or higher BMD (5, 6). Understanding the involvement of fat depots on bone integrity is increasingly needed considering the growing prevalence of obesity and type 2 diabetes notably in the ageing population.

Bone development and renewal rely on the activities of osteoclasts and osteoblasts, which resorb and form the mineralized matrix, respectively. During the developmental stages, both cells act rather independently to shape and allow the growth of bone. Once the peak bone mass is achieved, its maintenance throughout the adult life mainly involves the bone remodelling process to remove the old and damaged bone and to contribute to whole body calcium homeostasis. Bone remodelling consists in the sequential activities of the activated osteoclasts followed by the recruited osteoblasts: bone resorption and formation are thus timely and locally coupled so that the amount of removed bone is balanced by the amount of newly formed one (7). With ageing, bone remodelling progressively becomes uncoupled with an insufficient formation response to the resorption level. This uncoupling phenomenon is also prominent in the setting of menopause when the increase in bone formation fails to compensate for the rapid and continuous bone resorption. The resulting bone mass loss and micro architectural deterioration, mainly at trabecular but also cortical sites, characterize osteoporosis and lead to fragility fractures (7). Current osteoporosis treatment includes anti-catabolic or anabolic drugs used alone or in combination, which unfortunately cannot prevent all types of fractures and may be inefficient on the long term $(8,9)$.

The control of bone remodelling is multifactorial and driven by hormones such as oestrogens, parathyroid hormone, growth hormone, glucocorticoids but also numerous local factors. Indeed, bone cells such as the osteocytes (the osteoblast-derived cells imbedded within the bone matrix) and bone marrow (BM) cells tightly regulate their respective activities. BM also provides an essential environment by hosting the haematopoietic stem cells of which the myeloid precursors that are activated into osteoclasts and the bone marrow mesenchymal stem cells (BM-MSC) that give rise to osteoblasts (7). Among other haematopoietic, stromal, endothelial and neuronal cells, bone marrow adipocytes (BMAs) have recently emerged as an active component of the bone and the BM environment $(10,11)$.

$\mathrm{BM}$ adiposity represents up to $5 \%$ of total fat mass in healthy adults and constitutes an original and heterogeneous fat depot whose characteristics differ from the more commonly studied brown or subcutaneous and visceral white adipose tissues (10). BMA reside within the cavities of long bones and vertebrae in close vicinity of trabeculae. Different waves of BMA arise during bone growth and bone remodelling in humans and animal models (12). Importantly, the amount of BM adiposity is negatively associated with BMD in primary osteoporosis such as in ageing or menopause but also in secondary osteoporosis such as in anorexia nervosa. More evidence highlight how BMA differentiate from BM-MSC in response to typical regulators of bone remodelling and can also be a paracrine source of factors regulating osteoclatogenesis and/or osteoblastogenesis. In this review, clinical and fundamental data are collated to address both the pathophysiological conditions and the main BM and endocrine factors that interfere with the development and the activities of BMA, in order to discuss the current arguments that support but also challenge the involvement of BMA in the bone mass integrity.

\section{Physiological and pathological conditions associated with BMA development}

\section{BMA develop throughout life in close connection to bone status}

BM adiposity first develops during childhood and adolescence. The gradual replacement of the active haematopoietic BM by adipocytes was primarily reported to start in the appendicular skeleton: already present in the phalanges at the first year of life, BMA spread in the diaphysis up to the metaphysis of long bones during the following decades $(13,14)$. Besides, a very rapid accrual of BM adiposity has recently been described in the lumbar vertebrae during the first 2 years of life (15). Thus, BMA development appears as a physiological process concomitant to bone growth, which suggests its involvement in the acquisition of the peak bone mass. Indeed, in pre-pubertal girls, femoral BM fat content is positively associated with total bone mineral content (13). Perturbations in the peak bone mass achievement are believed to have adverse long-term effects on adulthood bone health as feared in paediatric osteoporosis (16) or with anorexia nervosa, a prevalent disorder in adolescent girls (4). However, BM fat development in femoral and tibial metaphysis remains strongly associated with age in adolescent girls suffering a mild-to-moderate anorexia nervosa, and, BM fat fraction is still positively correlated with BMD in the youngest patients identified as skeletally 
immature (17). Moreover, reviewing the skeletal phenotype of various lipodystrophy types, Scheller and Rosen conclude that none of adipose tissues is instrumental in the basic bone formation. Nevertheless, maintenance of BM adiposity development could contribute to bone protection against cyst formation during adolescence and pathological fractures in adulthood (14). Yet, analyses of $\mathrm{BM}$ fat remain scarce in very young subjects and nonexistent in childhood osteoporosis to our knowledge. As murine models of osteogenesis imperfecta (18) or Marfan syndrome (19) exhibit altered BMA development, investigating BM adiposity in paediatric bone disorders could also clarify its involvement in bone accrual and skeletal integrity later in life.

In the young adults with mature skeleton, the remaining haematopoietic sites within the proximal metaphysis of femur and humerus (20) and the lumbar vertebrae $(21,22)$ are progressively invaded by BMA. The increase rate of BMA accumulation is then slow with a $\sim 6 \%$ increase of fat per decade as assessed in vertebrae (21). $\mathrm{BM}$ adiposity proportion is higher in men than in women at least up to the menopause age $(20,22)$. Importantly, in that ageing-related step, BM accumulation is negatively associated with BMD $(22,23)$ and with trabecular bone quantity $(24,25)$ at different skeletal sites. Thus, even though BM adiposity development appears as a continuous physiological process throughout life, a switch in its association with bone mass occurs with the bone growth arrest. Whether this switch is causal, consecutive or unrelated to the physiological bone status has to be determined and could propel research on BM adiposity.

\section{Two BMA subpopulations for different periods of development in rodents}

The use of osmium tetroxide staining visualized by nano- and micro- CT has recently documented the developmental process of $\mathrm{BM}$ adiposity in rodents and leads to the definition of two BMA subpopulations. In 1- to 4-week-old mice, distal tibiae and caudal vertebrae rapidly display an expansion of adipocytes. This first early developed subset - whose amount remains relatively stable during pathophysiological challenges or ageing - has been referred as to constitutive BMA (cBMA) (12). From 12 -week-old and beyond, a second subset develops within the middle and proximal tibia, a site characterized by the presence of cancellous bone and high remodelling. Despite differences in the developmental rates between mouse strains, the amount of this BMA subpopulation correlates negatively with the trabecular number of proximal tibia.
This BMA subset - which arises scattered among the haematopoietic cells - has been referred to as regulated BMA (rBMA) (12) since its development is observed and modulated with ageing $(12,26,27)$ or pathophysiological conditions $(12,27,28)$. Importantly, the rBMA are reported to phenotypically differ from cBMA by a smaller size and a lower content in unsaturated fatty acids (12). The rBMA have been proposed to be preferentially distributed within the mid-to-proximal tibia, the femur and the lumbar vertebrae though cBMA could also be present in some of these areas (11). Actually, this recent classification into two subtypes might be oversimplified. Regarding its definition, for example, the 'unresponsive cBMA' can significantly expand within the distal part of the tibia-fibula junction following ovariectomy (S Lucas, personal communication). Moreover, as indicated through the characterization of BM-MSC-derived adipocytes, a greater heterogeneity in BMA properties can be expected according to the bone region (epiphysis, metaphysis and diaphysis) (29) or the bone type (long bones versus vertebrae) as well as the pathophysiological conditions as emphasized in the following sections. Extrapolation of such classification to humans also remains elusive. Indeed, some striking differences have to be considered when comparing animal models and human pathophysiological conditions. Compared to humans, the relative proportion of BM adiposity appears lower in mouse models (12). The mouse skeleton maturity is delayed to the adulthood since femoral (30) and vertebral (31) longitudinal growth continues to slowly increase up to the age of 6 and 10 months respectively, which is a period associated with rBMA development. Finally, females exhibit a much more enrichment in tibial rBMA than males $(11,29)$. Whether this trait is related to the early and fast trabecular bone loss occurring in these females $(27,28)$ has not been assessed yet but deserves further investigations considering the close associations between BMA and bone remodelling.

\section{BM adiposity is associated with bone loss}

From the initial biopsy analyses to the most adapted MRI or spectroscopy techniques, BM adiposity content has been shown to increase with ageing in various cross-sectional studies $(23,24)$. Importantly, the relative amount of BM adiposity has been negatively associated with bone quantity measured as areal BMD using whole body or regional DEXA (dual energy X-ray absorptiometry) or trabecular bone volume using QCT (quantitative CT). The BM fat proportion locally measured has been found to be inversely correlated with the trabecular bone 
volume in iliac crest biopsies (24), with the trabecular BMD in lumbar vertebrae $(25,32,33,34)$ and with the pelvic BMD $(23,35)$. In some studies, the relative BM fat proportion measured at a specific site (often the spine) can even be negatively associated with the whole body BMD $(23,35)$ or other bone site BMD $(33,34)$, which is surprising considering the expected heterogeneity of BMA development and phenotype according to the site and the potential interference of BMA in the local bone remodelling. This inverse relationship has been reported in young or old men and women $(23,24,35$, $36)$, even though post-menopausal women can exhibit the most consistent association compared to old men $(33,34)$. Indeed, women experience a rapid loss of bone and a spurt of BMA development at menopause (22). Importantly, the vertebral BM fat content is increased in osteopenic and osteoporotic subjects compared to those with normal BMD in aged men (37) and post-menopausal women $(34,38,39)$. Higher BM adiposity levels are also depicted in conditions where bone density is reduced secondary to anorexia nervosa (40), immobilization (41), glucocorticoid (42) or some thiazolidinedione (43) treatments. Moreover, a few studies indicate a relationship between $\mathrm{BM}$ fat content and prevalent vertebral fractures as reviewed in (44). Interestingly, in post-menopausal women, the unsaturation level of the vertebral $\mathrm{BM}$ lipid fraction is decreased compared to controls (38) and is inversely associated with fragility fractures (45). In line with the phenotype of rBMA in rodents (12), these data suggest that, besides expansion, the metabolic profile of BMA could also play an essential role in bone alterations.

Enhanced BM adiposity formation is reported in animal models of ageing (27), ovariectomy (28), calorie restriction (46), skeletal unloading (47) or following glucocorticoid (48) or rosiglitazone (49) administration. In most studies, stimulating BMA development is accompanied with a reduced bone quantity, and these animal models provide useful insights in the underlying connections between bone and BM fat. However, a few studies report a failure to improve bone parameters by impairing BMA development notably in the ovariectomy model $(50,51,52)$. Besides challenging the current view of an inverse relationship between BM adiposity and bone mass, other issues can be gleaned from these studies. Firstly, the genetic or pharmacological manipulations used to hamper BM adipogenesis also reduce the amount of extramedullary fat depots $(51,52)$, which may interfere with the bone integrity restoration. Indeed, specifically targeting the BM adipogenesis process has become a critical issue. Secondly, bone formation stimulation is only reported in the ovary-intact rats whose BM adiposity was the lowest following a PPARG antagonist treatment (52) raising the hypothesis that BM adiposity has to be amply curtailed below a certain threshold to beneficially impact on bone. Thirdly, as emphasized earlier, BMA development is strain-, gender- and age dependent. It is thus expected that the effects of BM adiposity on bone mass exhibit strong age-related variations notably according to the onset of ovariectomy-induced oestrogen deficiency, which should be performed when animals are skeletally mature.

\section{BM adiposity status in other bone defects}

BM adiposity is induced in mice (53) and patients (54) following irradiation, which triggers bone loss and other skeletal alterations. Cancer cells in the BM also disrupt bone formation and resorption leading to bone lesions. Though not yet demonstrated, BMA could also support the progression of multiple myeloma cells or bone metastatic cells as discussed in $(55,56)$ respectively.

In obesity and type 2 diabetes, a higher risk of fractures is reported at some specific bone sites despite increased or unchanged BMD. These conditions elicit a low bone turnover and likely compromise bone quality $(5,6)$. The development of BM adiposity in obesity has been poorly addressed: vertebral BM fat content is found unchanged compared to control (57) and related $(32)$ or not $(57,58)$ with the amount of visceral fat. In contrast, BMA consistently accrue in the long bones of high-fat feeding rodents while skeletal changes vary according to the studies $(59,60)$. Interestingly, BMA accumulation is more pronounced in aged animals (61). In type 2 diabetic patients, $\mathrm{BM}$ fat content is reported unmodified $(62,58)$ or increased $(63)$ according to the skeleton site, but yet is positively associated with $\mathrm{HbA} 1 \mathrm{c}$ levels $(58,63)$. In accordance, bariatric surgery, which causes a lowering of both body weight and bone mass, reduces BM fat fraction only in patients with improved glycaemic control (64).

In conclusion, and as already discussed (10), BM adiposity strikingly differs from the main fat depots and its levels are modulated by different cues. Moreover, BM fat development can dissociate from bone mass alterations in some conditions such as growth and body weight loss in obesity. Yet, BM adiposity accretion is strongly age-related and often associated with BMD deficit supporting its involvement in bone remodelling uncoupling. 


\section{Potential mechanisms underlying the detrimental impact of BMA on bone}

As confirmed by lineage tracing studies in mice (61), osteoblasts and BMA originate from a common BM-MSC that can give rise to independent precursors committed either to the osteochondrogenic or the adipogenic lineages. Moreover, several factors reciprocally regulate adipogenesis and osteoblastogenesis. Consequently, an unbalanced shift toward adipogenesis is considered as a detrimental process for osteoblastogenesis and the maintenance of bone mass.

Besides, first in vitro and ex vivo characterizations support that BMA are active cells releasing several factors interfering with bone remodelling. Primary BMA from ageing mice can synthetize several pro-apoptotic cytokines (65) and inflammatory factors such as TNFA and IL6 (26). Primary human (66) and murine (67) BMA also express the pro-osteoclastogenic factor RANKL, which promotes osteoclast precursor differentiation through direct cell contact (66). In vitro co-culture (68) or conditioned medium $(63,69)$ models point out a paracrine activity of BMA. BM-MSC-derived adipocytes can release saturated fatty acids that negatively impact osteoblast function and survival (68). Finally, adipocytes, derived from BM stromal or mesenchymal stem cells (both referred as to BM-MSC in the review), can secrete factors altering osteoblastogenesis and favouring adipogenesis as described in the next section.

The balance between osteoblastogenesis and adipogenesis is indeed orchestrated by multiple signals, cytokines, hormones and metabolic factors acting in an autocrine/paracrine or an endocrine mode on MSC. All these factors are involved in the regulation of the lineage commitment and/or differentiation programmes of MSC, which require the activation of specific transcription factors such as osterix and RUNX2 for osteoblastogenesis and PPARG2 and CEBPA for adipogenesis. In that matter, PPARG appears as a critical molecular regulator since targeting PPARG expression or activation interferes with the differentiation programme of both adipogenesis and osteoblastogenesis as exemplified in $(70,71)$.

\section{The local control of osteoblastogenesis and adipogenesis in the bone marrow}

Among many signalling pathways, WNT/ $\beta$-catenin and bone morphogenetic proteins (BMP) signalling play prominent roles in the control of osteoblastogenesis and adipogenesis.

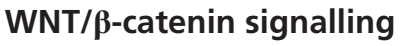

The canonical WNT/ $\beta$-catenin signalling pathway has been well established to play pro-osteogenic $(72,73)$ and anti-adipogenic $(73,74)$ effects on MSC. Briefly, WNT/ $\beta$ catenin signalling activation begins by the binding of WNT ligands with cell surface Frizzled receptors and requires the involvement of LDL receptor-related proteins 5,6 (LRP5/6) as co-receptors. This leads to $\beta$-catenin protein stabilization, accumulation then translocation to the nucleus where the protein acts as co-factor for stimulating specific gene targets (75). Thus, the regulation of WNT/ $\beta$ catenin signalling output is coordinated by a family of WNT secreted glycoprotein agonists found expressed by osteoblasts (72), preadipocytes (74) or BM-MSC (76). In addition, the pathway is negatively regulated by a variety of secreted antagonists: secreted Frizzled receptor proteins (SFRPs) including SFRP1 expressed by BM preadipocytes (73) and SFRP4 expressed in BM-MSCs (76) and BMA (26); Dickkopf-1 (DKK1) synthetized by BM-MSCs (76), BM preadipocytes (73), osteoblasts (77), and osteocytes (70); sclerotin secreted by osteocytes (78).

Both pro-osteogenic and anti-adipogenic effects of WNT/ $\beta$-catenin signalling have been demonstrated in various cell models by activating the pathway via inhibition of glycogen synthase kinase 3 beta (GSK3B) in BM-MSC (79) or $\beta$-catenin stabilization in the multipotent murine mesenchymal stem cell lines ST2 or C3H10T1/2 (80). Of note, in the 3T3-L1 cell line, $W N T / \beta$-catenin signalling and PPARG are reciprocally regulated to control adipogenesis (74). Most over experiments have modified the expression or availability of WNT agonists or antagonists. WNT3A treatment increases osteogenesis in BM-MSC (81) and in C3H10T1/2 cells for which adipogenesis is also inhibited (80, 81). Overexpression of Wnt1, Wnt10a or Wnt10b in ST2 cells attenuates adipogenesis and augments osteogenesis while depletion displays opposite effects (82). As for WNT antagonists, SFRP1 treatment of ST2 cells inhibits osteogenesis and stimulates adipogenesis (73). Next, DKK1 treatment stimulates adipogenesis of 3T3-L1 preadipocytes (74) while $D k k 1$ depletion results in decreased adipogenesis of D1 MSCs and pro-osteogenic effect on MC3T3-E1 cells and primary BM-MSCs (77). Finally, SOST addition exerts pro-adipogenic effects on primary murine and human BM-MSC (83).

The pro-osteogenic role of $\mathrm{WNT} / \beta$-catenin signalling has also been substantiated in vivo with reported functional mutations of LRP5 resulting in lower bone mass in humans $(81)$ and in mouse models $(72,80)$ associated 
with decreased osteoblast proliferation and bone formation activity. Moreover, deletion or overexpression of Sfrp1 (84), Dkk1 (77), Sfrp4 (85), Sost (86) increases or decreases, respectively, trabecular bone volume and osteoblast number. Neutralizing antibodies against SOST, alone or in combination with those against DKK1, are clinically assessed for the treatment of osteoporosis $(8,9)$. Besides bone volume alterations, in vivo $\beta$-catenin ablation in early cells of the osteoblast lineage increases BM adipogenesis (87). Additionally Sost deficiency (83) or $W n t 10 b$ overexpression (88) raises trabecular bone volume but lowers BM adiposity.

Besides its implication in the regulation of BM-MSC differentiation process, the $\mathrm{Wnt} / \beta$-catenin signalling promotes bone formation through several mechanisms. The pathway modulates the proliferation of preosteoblasts (72), controls the induction of apoptosis in osteoblasts and osteocytes (84); stimulates bone matrix synthesis and mineralization (77) and regulates osteoclastogenesis notably by promoting the osteoblast production of osteoprotegrin (89). Considering its critical roles, the Wnt/ $\beta$-catenin signalling is obviously a local downstream mediator of several bone-regulating hormones as developed in the 'Systemic control' section.

\section{BMP signalling}

BMPs are extracellular cytokines that are part of the transforming growth factor-beta (TGFB) superfamily and regulate numerous physiological processes including bone cell differentiation, bone formation, development and remodelling $(90,91)$. The most widely investigated BMP member consists in BMP2 that is produced by BM-MSC (92) or osteoblasts (93). The signalling is initiated through BMP binding to BMPR2 receptors, which led to the further activation of BMPR1 (90). The activated downstream components encompass many pathways and regulate lineage commitment and differentiation (94). In contrast to the $\mathrm{WNT} / \beta$-catenin signalling, BMP signalling stimulates both osteoblastogenesis and adipogenesis according to the availability of appropriate inductors in culture media $(92,95)$, the BMP concentration as the signalling may finely tune the MSC fate (96) and likely according to the activation of the proper receptor subtypes (BMPR1A versus BMPR1B) though their specificity for lineage differentiation remains unclarified (97). Importantly, both differentiation processes remain mutually exclusive (98). In vitro, pro-osteogenic and proadipogenic effects of BMP signalling are mainly evidenced by investigations of BMP2 treatment on C3H10T1/2 (90, 95) and ST2 cells (80).

Interestingly, both $\mathrm{BMP}$ and $\mathrm{WNT} / \beta$-catenin pathways play either antagonist (81) or cooperative (69) roles at various steps along bone cell lineage fate, differentiation and maturation. At early step, BMP signalling activation regulates MSC commitment to either osteoblastic or adipogenic lineages (95). Next, WNT/ $\beta$-catenin pathway activation is required to conduct osteochondrogenic progenitors to preosteoblasts (99). By then, both BMP signalling and $\mathrm{WNt} / \beta$-catenin signalling cooperate to promote osteoblast differentiation $(94,98)$ and selfrenewal (99), respectively. In the end, $\mathrm{WNt} / \beta$-catenin and BMP pathways exert opposite effects during osteoblast maturation: BMP signalling activation is still required to stimulate terminal osteogenic differentiation (95) and proper bone formation (91); meanwhile, WNT/ $\beta$ catenin signalling has to be inhibited in line with the late increased expression of the WNT antagonist SOST (78). Actually, osteocytes orchestrate bone formation via subtle variations of $\mathrm{WNT} / \beta$-catenin and $\mathrm{BMP}$ signalling to modulate osteoblast activity in response to their microenvironment (100). Nevertheless, the proosteogenic role of BMP signalling is well substantiated in vivo: Bmpr1 or Bmp2 depletions in mice respectively result in low bone mass (90) or deficient facture healing (101) while treatment with the BMP signalling antagonist gremlin (102) impaired bone formation.

\section{Other local signals and factors}

Most over-secreted factors are pro-osteogenic and display anti-adipogenic properties. The cytokine Hedgehog (HH) stimulates the commitment of murine MSC into osteoblastic lineage at the expense of adipogenesis (103). Its anti-adipogenic activity only occurs during the maturation phase in human BM-MSC (104). Moreover, $\mathrm{HH}$ signalling is reported to interact with BMP (93) and WNT/ $\beta$-catenin signalling (81). TGFB is another cytokine with pro-osteogenic effect (105) and an antiadipogenic role as reported in human BM-MSC (106). Fibroblast growth factor 2 (FGF2) - expressed by MSC, osteoblasts and osteocytes - also exerts pro-osteogenic and anti-adipogenic effects: Fgf2-deficient mice exhibit increased BM adiposity and decreased BMD $(107,108)$; conversely, FGF2 treatment abrogates the loss in bone formation (109) and reduces the adipogenic lineage potential of murine BM-MSC (110). The pro-osteogenic factor oncostatin produced by osteoblasts and osteocytes 
also has anti-adipogenic property on differentiating BM-MSCs (111).

Next, inflammatory cytokines, in serum or locally produced by various bone cells including BMA $(26,65)$, are associated with increased bone resorption notably in the setting of oestrogen decline (7). Interleukin -1 (IL1), -6 (IL6), -11 (IL11) and TNFA are well documented for their inhibitory effects on adipogenesis as shown in murine (112) and human BM-MSC (108). However, distinct osteogenic effects are reported according to one cytokine to another. Both IL6 and IL11 display pro-osteogenic effects on BM-MSC $(112,113)$, and $I 111$ expression in murine BM-MSC is inversely correlated to impaired bone formation during ageing (113). As reviewed in (107), contradictory effects are described for TNFA with both inhibitory and promoting activities on osteoblast differentiation. Lipocalin 2, recently found to be secreted by osteoblasts and myeloid cells, may upregulate osteoblastogenesis at the expense of adipogenesis as suggested in human BM-MSC (108). MCP1 has recently been reported as a factor released from BMA in type 2 diabetes to promote adipogenesis and partly alter osteoblastogenesis (63).

In contrast, the cell differentiation regulator DLK1/ PREF1, produced by several BM cells, exerts both antiosteogenic and anti-adipogenic roles as evidenced in human BM-MSC (114).

Remarkably, the BMA-secreted chemerin is one of the few factors which was demonstrated in vitro to be required for adipogenesis while negatively regulating osteoblastogenesis of murine BM-MSC (115). The involvement of two main adipokines, leptin and adiponectin, has obviously been investigated. Of note, the first phenotyping of primary mature adipocytes isolated from human (116) and murine (26) bone marrow samples strongly support that BMA express very low levels of leptin and adiponectin compared to extramedullary fat depots, notably in ageing (26) and in the post-menopausal status (S Lucas, personal communication). So far, a strong secretion of adiponectin from BMA has only been demonstrated in calorierestricted mice and has been associated with a systemic metabolic adaptation (88). Considering that BMA may not be a relevant local source of these two adipokines, leptin and adiponectin effects are thus discussed in the 'Metabolic hormones' section relative to the 'Systemic control'.

Collectively, most local characterized factors are proosteogenic with anti-adipogenic activities and can be dysregulated in diverse pathological conditions affecting
BMD. Interestingly, BM adipogenesis appears intimately interlinked with the bone microenvironment and partly regulated by several osteocyte-, osteoblast- and MSCsecreted factors. Moreover, the fact that BM preadipocytes and adipocytes can synthetize SFRP1, chemerin and MCP1 suggests that BMA themselves contribute to the control of their expansion (Fig. 1).

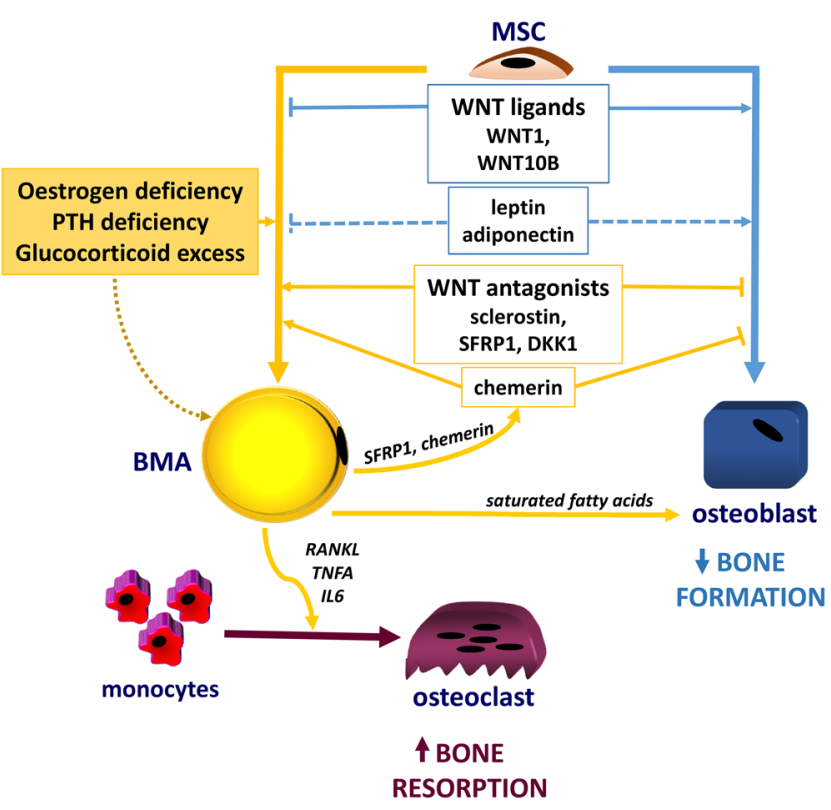

\section{Figure 1}

Potential mechanisms underlying the detrimental impact of BMA on bone remodelling. As shown on the top, bone marrow adipocytes (BMA) and osteoblasts arise from a common mesenchymal stem cell (MSC). Local osteogenic factors such as the WNT ligands WNT1 (synthetized by osteoblasts) and WNT10B impair adipogenesis. The local effects of leptin and adiponectin are still discussed (as mentioned in the text). The WNT antagonists such as sclerostin (secreted by osteocytes), DKK1 (synthetized by MSC, osteoblasts and osteocytes) or SFRP1 (secreted by MSC and bone marrow preadipocytes) inhibit osteoblastogenesis and promote adipogenesis. Oestrogen deficiency, parathyroid hormone (PTH) deficiency or glucocorticoid excess promote adipogenesis. These conditions could also alter the activity of BMA (as mentioned in the text). As shown at the bottom, BMA could support osteoclastogenesis through the synthesis of RANKL, TNFA and IL6. BMA could also preferentially release saturated fatty acids that alter osteoblast function and survival. Finally, BMA could stimulate its own expansion by secreting SFRP1 and chemerin, which are both pro-adipogenic and anti-osteoblastogenic. 


\section{The systemic control of BM osteoblastogenesis and adipogenesis}

\section{Sex steroids}

Oestrogens and androgens stimulate the growth spurt and promote bone mass acquisition at puberty through the growth hormone/insulin-like growth factor-1 (GH/ IGF1) axis stimulation and direct effects on bone cells. Sex steroids also contribute to bone mass maintenance in adulthood by slowing bone remodelling and tuning bone resorption and formation in a balanced mode (117). MSC, osteoblasts, osteocytes, myeloid precursors and osteoclasts express the two oestrogen receptor ESR1 and ESR2 and the androgen receptor AR. Mouse models of global or cell-specific deletions of each receptor have clarified the involvement of sex steroids, which is rather complex and vary according to the cortical or trabecular bone compartment, the cell type, the age and the sex (as deeply discussed in $(117,118))$.

The decline of oestrogen (more specifically $17 \beta$-oestradiol, E2) production at menopause triggers bone mass loss and is the main factor contributing to osteoporosis in women. The discovery in men that testosterone is converted to E2 by aromatization and that serum bioavailable oestrogen level is a consistent independent predictor of BMD also supports the potential contribution of oestrogen deficiency in the age-related bone loss in men (118). In humans and animals, both oestrogen and androgen deficiency results in increased bone remodelling: bone resorption and to a lesser degree formation are stimulated which leads to a net decrease of bone mass.

As already emphasized, menopause (22) or ovariectomy and orchidectomy in animals (27) leads to a strong BM adiposity accrual. Studies in growing or skeletally mature rodents indicate a rapid increase of BM fat in femur or proximal tibia (as soon as 4 weeks $(28,51)$ ) that continues to expand up to 2-3 months following ovariectomy $(51,119,120)$. Following ovariectomy, the changes in trabecular bone and the activity of osteoclasts and osteoblasts appear earlier than BMA development (121). Nevertheless, BMA amount continues to rise as the bone loss worsens (120) and a reciprocal relationship between BMA content and bone formation rate is observed (122). In premenopausal women with surgical bilateral oophorectomy, BMD reduction and BM fat accretion rapidly and concomitantly occur in the lumbar vertebrae and continue to evolve accordingly up to 21 months (123).
E2 exerts protective effects on bone via multiple mechanisms that notably involve suppression of bone resorption by inducing osteoclast apoptosis, reducing osteoclastogenic cytokine production and stimulating osteoprotegerin expression in osteoblasts. E2 also reduces osteoblast and osteocyte apoptosis (as reviewed in (117)). Importantly, in several murine BM stromal cell lines (98, 124), murine (98) or human BM-MSC (125), E2 promotes osteoblastogenesis and inhibits adipogenesis. The proosteoblastogenic effect of E2 relies on various molecular pathways such as the WNT (126) or BMP-4 (127) signalling pathways. Studies using BM stromal cells from several murine ER deletion models support that E2 suppresses the adipocyte lineage commitment and reduces adipocyte lipogenesis through ESR1 (128, 129). Moreover, E2 administration in ovariectomized rodents $(119,130)$ or in post-menopausal women $(131,132)$ rapidly decreases the amount of BM adiposity by preventing the BM adipocyte number accrual and reducing the adipocyte size. This can be observed before any restoration of the trabecular bone volume suggesting a high E2 sensitivity of the BM adiposity component.

Altogether many data consistently support the hypothesis that oestrogen deficiency diverts MSC differentiation from osteoblastogenesis toward adipogenesis, and this mechanism could significantly contribute to bone loss. Yet, as already discussed, early adipogenesis blocking failed to ameliorate bone parameters in ovariectomized rodents $(50,51,52)$. On the other hand, oestrogen deficiency could also alter mature osteoblast and adipocyte functions and future studies should therefore better address the BMA functions in the unbalanced bone remodelling following oestrogen decline.

\section{Glucocorticoids}

Even though a physiological level of glucocorticoids is instrumental in normal bone development, hypercortisolism or long-term glucocorticoid-based therapies are the most common cause of secondary osteoporosis and predispose to increased fractures in trabeculae-enriched bones (133). Following a transient resorption stimulation, bone formation is reduced, which becomes a clinical outcome in glucocorticoid-induced osteoporosis (GIOP). Besides their systemic impact on several hormonal axes, glucocorticoids exert direct effects on many bone and BM cells: MSC, osteoblasts and adipocytes express the nuclear glucocorticoid receptor 
and the two enzymes $11 \beta-H S D$ that intracellularly metabolize glucocorticoids $(134,135,136)$. As shown in the long bones of glucocorticoid-treated animals $(77,137), \mathrm{BM}$ adiposity accrual is concomitant to (or even precede (48)) the decrease in BMD, trabecular bone or osteoblast number.

Both in vitro and in vivo, glucocorticoid excess impairs osteogenesis notably by promoting osteoblast apoptosis (as reviewed in (99)) but also by inhibiting osteoblast differentiation through a GSK3B-mediated reduction of $\beta$-catenin activity (137). Pharmacological doses of glucocorticoids also stimulate osteoblast expression of several WNT signalling inhibitors such as DKK1 whose inhibition can prevent bone loss $(77,136)$. While a low concentration of dexamethasone is a common osteoinducer for cultured BM-MSC, increased concentrations trigger adipogenesis (138). Glucocorticoid signalling also seems crucial in vivo since $H s d 11$ b1 deletion abrogates BM adipogenesis (134). The glucocorticoidinduced disruption of BM-CSM differentiation leading to increased expression of Pparg2 or Cebpa has been linked to epigenetic regulations through the downregulation of WNT signalling $(139,140)$. However, both increased adipogenesis and unchanged osteogenesis have been reported in BM-MSC from a mouse GIOP model (27). These data point out that glucocorticoid excess does not always compromise BM-MSC commitment toward osteoblastogenesis in agreement with (138). Moreover, dexamethasone can regulate in vitro or ex vivo BMA functions by stimulating their lipolysis (68), upregulating RANKL expression (66) or perturbing adiponectin and leptin secretion $(68,141)$.

Deleterious glucocorticoid impact on bone mass involves several cell types and cellular mechanisms that include BM-MSC differentiation shift toward adipogenesis and the contribution of mature BMA to the altered bone remodelling through released factors. Of note, BM fat evolvement remains poorly examined in GIOP and deserves further investigations.

\section{Parathyroid hormone}

Parathyroid hormone (PTH) is a major regulator of calcium homeostasis partly through its direct stimulating actions on bone remodelling. As exemplified with primary hyperparathyroidism, continuous exposure to high levels of PTH results in the increase of bone resorption that exceeds bone formation, thus leading to bone loss. The stimulated osteoclast activity appears to rely on the unbalanced production of RANKL and osteoprotegerin by osteoblasts and osteocytes, which express the main receptor PTH1R (142). In contrast, intermittent administration (once daily) of PTH - or its short fragment PTH1-34 teriparatide - promotes bone formation to a greater extent than resorption. This anabolic effect increases trabecular bone mass in various animal models (142) and teriparatide is thus used to treat osteoporosis and to prevent fractures $(8,9)$. Indeed, intermittent PTH administration decreases sclerostin expression by osteocytes, prevents osteoblast apoptosis (142) and promotes osteoblast differentiation from BM-MSC via BMP signalling enhancement (143) or via $\beta$-catenin stabilization through a LRP6/PTH1R complex (144). Lineage tracing studies in mice also revealed that teriparatide reactivates quiescent lining cells (145) or stimulates osteoblast precursor proliferation (146) to become active osteoblasts.

Several evidence support that PTH also elicits bone anabolic effect by inhibiting adipogenesis. Intermittent teriparatide exposure of human BM-MSC reduces adipocyte differentiation even in pro-adipogenic conditions (147). PTH treatment of ovariectomized rats increases BMD but lowers BM adiposity (148). In mice, Pth1r ablation in mesenchymal progenitors results in both reduced trabecular and cortical bone volume and a marked increase of BMA (67). Moreover, withdrawal of intermittent teriparatide administration increases the density of BMA that partly derive from osteoblast precursors; such cell fate switch is associated with a suppressed $\beta$-catenin activity (146). Finally, teriparatide administration rapidly improves bone density and reduces BM fat fraction at lumbar spine in post-menopausal women (149) and lowers BMA number in the iliac crest of osteoporotic men (67).

Altogether, PTH appears as a critical factor to determine the cell fate between osteoblast and adipocyte. Besides, the loss of PTH signalling increases several adipocyte factors and stimulates RANKL synthesis in murine BMA (67) supporting that PTH can also alter the activity of BMA.

\section{The GH/IGF1 axis}

The GH/IGF1 axis is an important regulator of growth and peak bone mass achievement and contributes to bone maintenance in adulthood (150). Serum levels of GH and its downstream mediator IGF1 decline with ageing in association with bone loss suggesting their involvement in osteoporosis pathogenesis $(9,150)$. Moreover adult-onset 
$\mathrm{GH}$ deficiency is associated with reduced BMD and a higher risk of fractures; GH replacement therapy increases BMD on the long term (reviewed in (9)).

IGF1 is a peptide with insulin-like properties, mainly produced by the liver under the GH control but also by osteoblasts in tight collaboration with the PTH. IGF1 activity is mediated by the IGF1 receptor (IGF1R) and is highly dependent on its bioavailability and transport by binding proteins (150).

In vitro data are scarce and support that IGF1 stimulates MSC proliferation and promotes both adipogenic and osteoblastogenic differentiation $(151,152)$. IGF1 signalling in osteoblasts is also critical for bone mineralization as evidenced by multiple murine models (150). BM adiposity has been poorly assessed in vivo: IGF1 appears ineffective on BMA levels in mice with $I g f 1$ liver deficiency and following administration in hypophysectomized rats (153), which suggests that the IGF1 pathway is not critical for BM adipogenesis.

$\mathrm{GH}$ is expected to elicit IGF1-independent effects since BM-MSC, osteoblasts, osteocytes, osteoclasts and adipocytes express the receptor for GH (150). The reported direct effects of $\mathrm{GH}$ are scarce but include the proliferation and the osteogenic differentiation of human osteoblastlike cells (154). GH differently influences adipocyte differentiation according to the cell type. In GH-deficient dwarf rats (155) and in hypophysectomized rats (153), both number and size of BMA are increased while trabecular bone, osteoblast number or mineralization perimeter are decreased. In both models, GH administration improves bone parameters and lowers BMA density and diameter, whereas IGF1 administration has barely any impact on BMA. Surprisingly, divergent results were obtained from the in vitro study of BM-MSC from hypophysectomized rats supporting that lack and restoration of GH level decreases and increases the preadipocyte pool respectively (153, 156). Besides, GH administration in obese premenopausal women increases serum bone formation markers and BM fat in vertebrae (157). Further studies are thus required to clarify if reduced GH signalling is really involved in the reciprocal changes of bone and fat.

\section{Metabolic hormones}

Several other hormones interact with bone mass and BM adiposity including leptin and adiponectin whose influences are complex. Leptin raises a tremendous interest since either hyperleptinemia in obesity or hypoleptinemia in anorexia nervosa could underlie the increase in bone fragility observed in these two conditions. Leptin actions on bone mass have been believed to be mediated mainly through a hypothalamic relay, which stimulates the sympathetic tone and regulates several hormonal axes such as the sex steroids, cortisol and GH ones (1). Besides leptin exerts peripheral effects, which can now be regarded as more dominant than the central effects as proposed in $(158,159,160)$. Leptin notably impacts on the lineage commitment of both human (161) and murine (162) BM-MSC in vitro. Lineage tracing studies have actually shown that most BM stromal cells express the main leptin transducing receptor (LEPR), which post-natally give rise to osteoblasts and adipocytes (163). Though controversial (163), osteoblasts and BMA can express LEPR (164). Various rodent models including leptin or Lepr disruption with or without leptin administration have been extensively studied and, yet, data are conflicting. Pioneer studies promoted that leptin negatively regulates bone mass through the sympathetic nervous system to inhibit osteoblast proliferation (165). In contrast, re-evaluation of the $\mathrm{Ob} / \mathrm{Ob}$ and $\mathrm{Db} / \mathrm{Db}$ models indicate that leptin positively impacts bone mass with variations according to the skeleton site (i.e. long bones versus vertebrae) and the bone region (i.e. trabecular or cortical site) $(158,166)$. Furthermore, peripheral as well as central leptin administration enhances bone formation by increasing both the number and activity of osteoblasts $(1,158)$. Concomitantly to trabecular bone reduction, an increase in BMA density is found in the long bones of $\mathrm{Ob} / \mathrm{Ob}$ (166) and $\mathrm{Db} / \mathrm{Db}$ mice (164) while BM adiposity is unchanged in lumbar vertebrae. Subcutaneous leptin administration in $\mathrm{Ob} / \mathrm{Ob}$ mice lowers the number of BMA and improves bone formation (167). Most in vitro studies support that leptin favours osteogenesis over adipogenesis as exemplified in (161). However, the lineage commitments of murine BM-MSC harbouring different disruptions in leptin signalling are quite variable (162). Characterization of the model with Lepr deletion specifically in BM-MSC has recently challenged this view. The study supports that leptin directly acts on MSC to inhibit osteogenesis and to drive adipogenesis in normal conditions and during high-fat diet; nevertheless, LEPR signalling seems unnecessary for irradiation-induced adipogenesis (160). Besides partly explaining the regional impact of leptin signalling, the study provides interesting clues regarding the disconnected effect of leptin administration on decreasing BM adiposity with no change in osteoblast number as observed during immobilization (168) or calorie restriction (169). Importantly, it highlights how permissive the pathophysiological context is for leptin impact on BMA adiposity. 
Adiponectin, whose plasma levels vary in the opposite of leptin ones, has obviously focused a lot of attention. Adiponectinemia can be found inversely correlated with BMD at different bone sites in anorexia nervosa (170), postmenopausal women and men (171) and in type 2 diabetes (172). Adiponectin actions on bone mass are centrally mediated or direct since osteoblastic and osteoclastic cells express the receptor ADIPOR1 (2). Various murine models have been investigated with very inconsistent outcomes regarding bone mass as reviewed in (2). Briefly, adiponectin decreases bone resorption through both central and peripheral mechanisms (173). Bone formation can be stimulated when adiponectin acts centrally to reduce the sympathetic tone (174) and inhibited when adiponectin directly targets osteoblasts (173) with an agedependent partitioning of these opposite pathways (174). To further illustrate the complexity, either adiponectin overexpression (175) or deletion (174) results in the increase of BM adiposity. In vitro studies confuse the issue since the adipokine is reported to prevent adipogenesis (176) and to favour osteoblast differentiation (177) of murine BM-MSC. Altogether data are thus difficult to reconcile. One may speculate that, as supported for leptin action and in (173), the pathophysiological conditions determine adiponectin targets and actions. The adiponectinaemia rise induced by calorie restriction has indeed been shown to be triggered by BMA to contribute to the metabolic adaptation of skeletal muscle (88).

Finally, fibroblast growth factor 21 (FGF21), which is mainly a hepatokine but can also be released by adipose tissue, has also recently been identified as a negative bone regulator by inhibiting osteoblastogenesis and stimulating adipogenesis in murine BM-MSC (178).

\section{Conclusions and perspectives}

BM-MSC commitment toward adipogenesis or osteoblastogenesis results from a complex interplay of both local and systemic factors. In most states with uncoupled bone remodelling and osteoporosis, BM adipogenesis is stimulated while osteoblastogenesis is impaired (Fig. 1). Though the two processes can independently be modulated (e.g. growth versus ageing, glucocorticoid excess (179), leptin impact (160)), much attention has been brought to the relationship of BMA with impaired bone formation. Yet, activation of the resorption process itself can promote $\mathrm{BM}$ adipogenesis (180) and anti-resorptive (181) treatment can reverse
BM adiposity in post-menopausal women. In line with their RANKL production $(66,67)$, BMA may thus play an unexpected and yet relevant role in the unbalanced bone remodelling by disrupting the osteoclast-osteoblast tandem classically considered in the resorption process regulation. This additional level of BMA involvement in bone metabolism through resorption definitively deserves further investigations and could clarify the independent modulation sometimes observed between osteoblastogenesis and adipogenesis.

Latest studies highlight the BMA heterogeneity, which is greater than previously anticipated notably regarding its location in either skeleton site (appendicular versus axial) or bone region (trabecular versus cortical). However, $\mathrm{BM}$ fat measurements in clinical studies remain mostly performed in the lumbar vertebrae $(32,33,45,58,62)$. Discrepancies between fundamental and clinical studies as exemplified in the obesity situation could be unravelled by further examination of other relevant skeleton sites. Fracture sites in obesity and type 2 diabetes can actually differ from the primary osteoporosis typical ones $(5,6)$ and clinical analysis of BM adiposity at these specific sites could better define if the BMA component is involved in these metabolic situations as recently exemplified (63).

Moreover, BMA development and properties also vary according to the pathophysiological context. Ageing, which exacerbates ovariectomy (130) or high-fat feeding (61) effects, is most likely a determinant context that encompasses a functional decline of $\operatorname{BM-MSC}(179,61)$ and an array of dysregulated mediators. Besides, BMA secretions could interfere with bone remodelling in a regulated manner $(66,67)$ (Fig. 1). Thus, as initially proposed (10), the BMA are most likely highly regulated cells whose phenotype and function should be considered according to each analysed pathophysiological condition and carefully extrapolated. With more investigations on these important issues, BM adiposity could become a reliable indicator of bone integrity in the management of osteoporosis.

\section{Declaration of interest}

The authors declare that there is no conflict of interest that could be perceived as prejudicing the impartiality of this review.

\section{Funding}

This work was supported by the Société Française de Rhumatologie (grant SFR-Network $\left.n^{\circ} 3764,2016\right)$ and the Université du Littoral-Côte d'Opale ULCO (post-doctoral fellowship for T Rharass, 2016-2017; grant BQR R/090217, 2017). 
Author contribution statement

$T R$ and $S \mathrm{~L}$ contributed to the design of the review, critically revised it, approved the final version to be published and agreed to be accountable for all aspects of the work. S L made the figure.

\section{Acknowledgement}

Writing of this review was enabled by ULCO University.

\section{References}

1 Upadhyay J, Farr OM \& Mantzoros CS. The role of leptin in regulating bone metabolism. Metabolism: Clinical and Experimental 201564 105-113. (https://doi.org/10.1016/j.metabol.2014.10.021)

2 Naot D, Musson DS \& Cornish J. The activity of adiponectin in bone. Calcified Tissue International 2017100 486-499. (https://doi. org/10.1007/s00223-016-0216-5)

3 Sheu Y \& Cauley JA. The role of bone marrow and visceral fat on bone metabolism. Current Osteoporosis Reports 20119 67-75. (https:// doi.org/10.1007/s11914-011-0051-6)

4 Misra M, Golden NH \& Katzman DK. State of the art systematic review of bone disease in anorexia nervosa. International Journal of Eating Disorders 201649 276-292. (https://doi.org/10.1002/ eat.22451)

5 Walsh JS \& Vilaca T. Obesity, type 2 diabetes and bone in adults. Calcified Tissue International 2017100 528-535. (https://doi. org/10.1007/s00223-016-0229-0)

6 Schwartz AV. Epidemiology of fractures in type 2 diabetes. Bone 2016 82 2-8. (https://doi.org/10.1016/j.bone.2015.05.032)

7 Rosen CJ. The epidemiology and pathogenesis of osteoporosis. In Endotext. Eds LJ De Groot, G Chrousos, K Dungan, KR Feingold, A Grossman, JM Hershman, C Koch, M Korbonits, R McLachlan, M New et al. South Dartmouth, MA: MDText.com, Inc., 2000.

8 Khosla S \& Hofbauer LC. Osteoporosis treatment: recent developments and ongoing challenges. Lancet Diabetes and Endocrinology 20175 898-907. (https://doi.org/10.1016/S22138587(17)30188-2)

9 Canalis E. Management of endocrine disease: novel anabolic treatments for osteoporosis. European Journal of Endocrinology 2018 178 R33-R44. (https://doi.org/10.1530/EJE-17-0920)

10 Hardouin P, Rharass T \& Lucas S. Bone marrow adipose tissue: to be or not to be a typical adipose tissue? Frontiers in Endocrinology 20167 85. (https://doi.org/10.3389/fendo.2016.00085)

11 Scheller EL, Cawthorn WP, Burr AA, Horowitz MC \& MacDougald OA. Marrow adipose tissue: trimming the fat. Trends in Endocrinology and Metabolism 201627 392-403. (https://doi. org/10.1016/j.tem.2016.03.016)

12 Scheller EL, Doucette CR, Learman BS, Cawthorn WP, Khandaker S, Schell B, Wu B, Ding SY, Bredella MA, Fazeli PK et al. Region-specific variation in the properties of skeletal adipocytes reveals regulated and constitutive marrow adipose tissues. Nature Communications 20156 7808. (https://doi.org/10.1038/ncomms8808)

13 Newton AL, Hanks LJ, Davis M \& Casazza K. The relationships among total body fat, bone mineral content and bone marrow adipose tissue in early-pubertal girls. BoneKEy Reports 20132315. (https://doi.org/10.1038/bonekey.2013.49)

14 Scheller EL \& Rosen CJ. What's the matter with MAT? Marrow adipose tissue, metabolism, and skeletal health: marrow adipose tissue and skeletal health. Annals of the New York Academy of Sciences 20141311 14-30. (https://doi.org/10.1111/nyas.12327)

15 Ruschke S, Pokorney A, Baum T, Eggers H, Miller JH, Hu HH \& Karampinos DC. Measurement of vertebral bone marrow proton density fat fraction in children using quantitative water-fat MRI.
Magma 201730 449-460. (https://doi.org/10.1007/s10334-017-06170)

16 Mäkitie O. Causes, mechanisms and management of paediatric osteoporosis. Nature Reviews Rheumatology 20139 465-475. (https:// doi.org/10.1038/nrrheum.2013.45)

17 Ecklund K, Vajapeyam S, Mulkern RV, Feldman HA, O'Donnell JM, DiVasta $\mathrm{AD} \&$ Gordon CM. Bone marrow fat content in 70 adolescent girls with anorexia nervosa: magnetic resonance imaging and magnetic resonance spectroscopy assessment. Pediatric Radiology 201747 952-962. (https://doi.org/10.1007/s00247-0173856-3)

18 Gioia R, Panaroni C, Besio R, Palladini G, Merlini G, Giansanti V, Scovassi IA, Villani S, Villa I, Villa A et al. Impaired osteoblastogenesis in a murine model of dominant osteogenesis imperfecta: a new target for osteogenesis imperfecta pharmacological therapy. Stem Cells 201230 1465-1476. (https://doi.org/10.1002/stem.1107)

19 Smaldone S, Clayton NP, Del Solar M, Pascual-Gonzales G, Cheng SH, Wentworth BM, Schaffler MB \& Ramirez F. Fibrillin-1 regulates skeletal stem cell differentiation by modulating TGF $\beta$ activity within the marrow niche. Journal of Bone and Mineral Research 201531 86-97. (https://doi.org/10.1002/jbmr.2598)

20 Pansini V, Monnet A, Salleron J, Hardouin P, Cortet B \& Cotten A. 3 Tesla (1) H MR spectroscopy of hip bone marrow in a healthy population, assessment of normal fat content values and influence of age and sex. Journal of Magnetic Resonance Imaging 201439 369-376. (https://doi.org/10.1002/jmri.24176)

21 Kugel H, Jung C, Schulte O \& Heindel W. Age- and sex-specific differences in the $1 \mathrm{H}$-spectrum of vertebral bone marrow. Journal of Magnetic Resonance Imaging 200113 263-268.

22 Griffith JF, Yeung DKW, Ma HT, Leung JCS, Kwok TCY \& Leung PC. Bone marrow fat content in the elderly: a reversal of sex difference seen in younger subjects. Journal of Magnetic Resonance Imaging 2012 36 225-230. (https://doi.org/10.1002/jmri.23619)

23 Shen W, Chen J, Punyanitya M, Shapses S, Heshka S \& Heymsfield SB. MRI-measured bone marrow adipose tissue is inversely related to DXA-measured bone mineral in Caucasian women. Osteoporosis International 200718 641-647. (https://doi. org/10.1007/s00198-006-0285-9)

24 Justesen J, Stenderup K, Ebbesen EN, Mosekilde L, Steiniche T \& Kassem M. Adipocyte tissue volume in bone marrow is increased with aging and in patients with osteoporosis. Biogerontology 20012 165-171.

25 Di Iorgi N, Rosol M, Mittelman SD \& Gilsanz V. Reciprocal relation between marrow adiposity and the amount of bone in the axial and appendicular skeleton of young adults. Journal of Clinical Endocrinology and Metabolism 200893 2281-2286. (https://doi. org/10.1210/jc.2007-2691)

26 Liu LF, Shen WJ, Ueno M, Patel S \& Kraemer FB. Characterization of age-related gene expression profiling in bone marrow and epididymal adipocytes. BMC Genomics 201112 212. (https://doi. org/10.1186/1471-2164-12-212)

27 Sui B, Hu C, Liao L, Chen Y, Zhang X, Fu X, Zheng C, Li M, Wu L, Zhao X et al. Mesenchymal progenitors in osteopenias of diverse pathologies: differential characteristics in the common shift from osteoblastogenesis to adipogenesis. Scientific Reports $2016 \mathbf{6} 30186$ (https://doi.org/10.1038/srep30186)

28 Kurabayashi T, Tomita M, Matsushita H, Honda A, Takakuwa K \& Tanaka K. Effects of a beta 3 adrenergic receptor agonist on bone and bone marrow adipocytes in the tibia and lumbar spine of the ovariectomized rat. Calcified Tissue International 200168 248-254. (https://doi.org/10.1007/s002230001203)

29 Cheng CC, Lian WS, Hsiao FSH, Liu IH, Lin SP, Lee YH, Chang CC, Xiao GY, Huang HY, Cheng CF et al. Isolation and characterization of novel murine epiphysis derived mesenchymal stem cells. PLOS ONE 20127 e36085. (https://doi.org/10.1371/journal.pone.0036085) 
30 Glatt V, Canalis E, Stadmeyer L \& Bouxsein ML. Age-related changes in trabecular architecture differ in female and male C57BL/6J mice. Journal of Bone and Mineral Research 200722 1197-1207. (https://doi. org/10.1359/jbmr.070507)

31 Buie HR, Moore CP \& Boyd SK. Postpubertal architectural developmental patterns differ between the L3 vertebra and proximal tibia in three inbred strains of mice. Journal of Bone and Mineral Research 200823 2048-2059. (https://doi.org/10.1359/jbmr.080808)

32 Bredella MA, Torriani M, Ghomi RH, Thomas BJ, Brick DJ, Gerweck AV, Rosen CJ, Klibanski A \& Miller KK. Vertebral bone marrow fat is positively associated with visceral fat and inversely associated with IGF-1 in obese women. Obesity 201119 49-53. (https://doi.org/10.1038/oby.2010.106)

33 Schwartz AV, Sigurdsson S, Hue TF, Lang TF, Harris TB, Rosen CJ, Vittinghoff E, Siggeirsdottir K, Sigurdsson G, Oskarsdottir D, Shet K, Palermo L, Gudnason V \& Li X. Vertebral bone marrow fat associated with lower trabecular BMD and prevalent vertebral fracture in older adults. Journal of Clinical Endocrinology and Metabolism 201398 2294-2300. (https://doi.org/10.1210/jc.2012-3949)

34 Li GW, Xu Z, Chen QW, Tian YN, Wang XY, Zhou L \& Chang SX. Quantitative evaluation of vertebral marrow adipose tissue in postmenopausal female using MRI chemical shift-based waterfat separation. Clinical Radiology 201469 254-262. (https://doi org/10.1016/j.crad.2013.10.005)

35 Shen W, Chen J, Gantz M, Punyanitya M, Heymsfield SB, Gallagher D, Albu J, Engelson E, Kotler D, Pi-Sunyer X et al. MRImeasured pelvic bone marrow adipose tissue is inversely related to DXA-measured bone mineral in younger and older adults. European Journal of Clinical Nutrition 201266 983-988. (https://doi. org/10.1038/ejcn.2012.35)

36 Gao Y, Zong K, Gao Z, Rubin MR, Chen J, Heymsfield SB, Gallagher D \& Shen W. Magnetic resonance imaging-measured bone marrow adipose tissue area is inversely related to cortical bone area in children and adolescents aged 5-18 years. Journal of Clinical Densitometry 201518 203-208. (https://doi.org/10.1016/j. jocd.2015.03.002)

37 Griffith JF, Yeung DKW, Antonio GE, Lee FKH, Hong AWL, Wong SYS, Lau EMC \& Leung PC. Vertebral bone mineral density, marrow perfusion, and fat content in healthy men and men with osteoporosis: dynamic contrast-enhanced MR imaging and MR spectroscopy. Radiology 2005236 945-951. (https://doi.org/10.1148/ radiol.2363041425)

38 Yeung DKW, Griffith JF, Antonio GE, Lee FKH, Woo J \& Leung PC. Osteoporosis is associated with increased marrow fat content and decreased marrow fat unsaturation: a proton MR spectroscopy study. Journal of Magnetic Resonance Imaging 200522 279-285. (https://doi. org/10.1002/jmri.20367)

39 Griffith JF, Yeung DKW, Antonio GE, Wong SYS, Kwok TCY, Woo J \& Leung PC. Vertebral marrow fat content and diffusion and perfusion indexes in women with varying bone density: MR evaluation. Radiology 2006241 831-838. (https://doi.org/10.1148/ radiol.2413051858)

40 Bredella MA, Fazeli PK, Miller KK, Misra M, Torriani M, Thomas BJ, Ghomi RH, Rosen CJ \& Klibanski A. Increased bone marrow fat in anorexia nervosa. Journal of Clinical Endocrinology and Metabolism 200994 2129-2136. (https://doi.org/10.1210/jc.2008-2532)

41 Trudel G, Payne M, Mädler B, Ramachandran N, Lecompte M, Wade C, Biolo G, Blanc S, Hughson R, Bear L \& Uhthoff HK. Bone marrow fat accumulation after 60 days of bed rest persisted 1 year after activities were resumed along with hemopoietic stimulation: the Women International Space Simulation for Exploration study. Journal of Applied Physiology 2009107 540-548. (https://doi. org/10.1152/japplphysiol.91530.2008)

42 Vande Berg BC, Malghem J, Lecouvet FE, Devogelaer JP, Maldague B \& Houssiau FA. Fat conversion of femoral marrow in glucocorticoid-treated patients: a cross-sectional and longitudinal study with magnetic resonance imaging. Arthritis and Rheumatism 199942 1405-1411. (https://doi.org/10.1002/15290131(199907)42:7<1405::AID-ANR14>3.0.CO;2-W)

43 Grey A, Beckley V, Doyle A, Fenwick S, Horne A, Gamble G \& Bolland M. Pioglitazone increases bone marrow fat in type 2 diabetes: results from a randomized controlled trial. European Journal of Endocrinology 2012166 1087-1091. (https://doi.org/10.1530/EJE11-1075)

44 Paccou J, Penel G, Chauveau C, Cortet B \& Hardouin P. Marrow adiposity and bone: review of clinical implications. Bone 2018. (https://doi.org/10.1016/j.bone.2018.02.008)

45 Patsch JM, Li X, Baum T, Yap SP, Karampinos DC, Schwartz AV \& Link TM. Bone marrow fat composition as a novel imaging biomarker in postmenopausal women with prevalent fragility fractures. Journal of Bone and Mineral Research 201328 1721-1728. (https://doi.org/10.1002/jbmr.1950)

46 Devlin MJ, Cloutier AM, Thomas NA, Panus DA, Lotinun S, Pinz I, Baron R, Rosen CJ \& Bouxsein ML. Caloric restriction leads to high marrow adiposity and low bone mass in growing mice. Journal of Bone and Mineral Research 201025 2078-2088. (https://doi. org/10.1002/jbmr.82)

47 Ahdjoudj S, Lasmoles F, Holy X, Zerath E \& Marie PJ. Transforming growth factor beta2 inhibits adipocyte differentiation induced by skeletal unloading in rat bone marrow stroma. Journal of Bone and Mineral Research 200217 668-677. (https://doi.org/10.1359/ jbmr.2002.17.4.668)

48 Li GW, Xu Z, Chen QW, Chang SX, Tian YN \& Fan JZ. The temporal characterization of marrow lipids and adipocytes in a rabbit model of glucocorticoid-induced osteoporosis. Skeletal Radiology $2013 \mathbf{4 2}$ 1235-1244. (https://doi.org/10.1007/s00256-013-1659-7)

49 Ali AA, Weinstein RS, Stewart SA, Parfitt AM, Manolagas SC \& Jilka RL. Rosiglitazone causes bone loss in mice by suppressing osteoblast differentiation and bone formation. Endocrinology 2005 146 1226-1235. (https://doi.org/10.1210/en.2004-0735)

50 Akune T, Ohba S, Kamekura S, Yamaguchi M, Chung UI, Kubota N, Terauchi Y, Harada Y, Azuma Y, Nakamura K et al. PPARgamma insufficiency enhances osteogenesis through osteoblast formation from bone marrow progenitors. Journal of Clinical Investigation 2004 113 846-855. (https://doi.org/10.1172/JCI19900)

51 Iwaniec UT \& Turner RT. Failure to generate bone marrow adipocytes does not protect mice from ovariectomy-induced osteopenia. Bone 201353 145-153. (https://doi.org/10.1016/j.bone.2012.11.034)

52 Li G, Xu Z, Hou L, Li X, Li X, Yuan W, Polat M \& Chang S. Differential effects of bisphenol A diglicydyl ether on bone quality and marrow adiposity in ovary-intact and ovariectomized rats. American Journal of Physiology: Endocrinology and Metabolism 2016311 E922-E927. (https://doi.org/10.1152/ajpendo.00267.2016)

53 Chandra A, Lin T, Young T, Tong W, Ma X, Tseng WJ, Kramer I, Kneissel M, Levine MA, Zhang Y et al. Suppression of sclerostin alleviates radiation-induced bone loss by protecting bone-forming cells and their progenitors through distinct mechanisms. Journal of Bone and Mineral Research 201732 360-372. (https://doi.org/10.1002/ jbmr.2996)

54 Mostoufi-Moab S, Magland J, Isaacoff EJ, Sun W, Rajapakse CS, Zemel B, Wehrli F, Shekdar K, Baker J, Long J et al. Adverse fat depots and marrow adiposity are associated with skeletal deficits and insulin resistance in long-term survivors of pediatric hematopoietic stem cell transplantation. Journal of Bone and Mineral Research 201530 1657-1666. (https://doi.org/10.1002/jbmr.2512)

55 Falank C, Fairfield H \& Reagan MR. Signaling interplay between bone marrow adipose tissue and multiple myeloma cells. Frontiers in Endocrinology 20167 67. (https://doi.org/10.3389/fendo.2016.00067)

56 Hardaway AL, Herroon MK, Rajagurubandara E \& Podgorski I. Bone marrow fat: linking adipocyte-induced inflammation with skeletal metastases. Cancer Metastasis Reviews 201433 527-543. (https://doi. org/10.1007/s10555-013-9484-y) 
57 Ermetici F, Briganti S, Delnevo A, Cannaò P, Leo GD, Benedini S, Terruzzi I, Sardanelli F \& Luzi L. Bone marrow fat contributes to insulin sensitivity and adiponectin secretion in premenopausal women. Endocrine 201859 410-418. (https://doi.org/10.1007/ s12020-017-1349-7)

58 de Araújo IM, Salmon CEG, Nahas AK, Nogueira-Barbosa MH, Elias J $\&$ de Paula FJA. Marrow adipose tissue spectrum in obesity and type 2 diabetes mellitus. European Journal of Endocrinology 2017176 21-30. (https://doi.org/10.1530/EJE-16-0448)

59 Doucette CR, Horowitz MC, Berry R, MacDougald OA, AnunciadoKoza R, Koza RA \& Rosen CJ. A high fat diet increases bone marrow adipose tissue (MAT) but does not alter trabecular or cortical bone mass in C57BL/6J mice. Journal of Cellular Physiology 2015230 2032-2037. (https://doi.org/10.1002/jcp.24954)

60 Tencerova M, Figeac F, Ditzel N, Taipaleenmäki H, Nielsen TK \& Kassem M. High-fat diet-induced obesity promotes expansion of bone marrow adipose tissue and impairs skeletal stem cell functions in mice. Journal of Bone and Mineral Research 201833 1154-1165. (https://doi.org/10.1002/jbmr.3408)

61 Ambrosi TH, Scialdone A, Graja A, Gohlke S, Jank AM, Bocian C, Woelk L, Fan H, Logan DW, Schürmann A, Saraiva LR et al. Adipocyte accumulation in the bone marrow during obesity and aging impairs stem cell-based hematopoietic and bone regeneration. Cell Stem Cell 201720 771.e6-784.e6. (https://doi.org/10.1016/j.stem.2017.02.009)

62 Kim TY, Schwartz AV, Li X, Xu K, Black DM, Petrenko DM, Stewart L, Rogers SJ, Posselt AM, Carter JT et al. Bone marrow fat changes after gastric bypass surgery are associated with loss of bone mass. Journal of Bone and Mineral Research 201732 2239-2247. (https://doi. org/10.1002/jbmr.3212)

63 Ferland-McCollough D, Masseli D, Spinetti G, Sambataro M, Sullivan N, Blom A \& Madeddu P. MCP-1 feedback loop between adipocytes and mesenchymal stromal cells causes fat accumulation and contributes to hematopoietic stem cell rarefaction in the bone marrow of diabetic patients. Diabetes 201867 1380-1394. (https:// doi.org/10.2337/db18-0044)

64 Yu EW, Greenblatt L, Eajazi A, Torriani M \& Bredella MA. Marrow adipose tissue composition in adults with morbid obesity. Bone 2017 97 38-42. (https://doi.org/10.1016/j.bone.2016.12.018)

65 Gasparrini M, Rivas D, Elbaz A \& Duque G. Differential expression of cytokines in subcutaneous and marrow fat of aging C57BL/6J mice. Experimental Gerontology 200944 613-618. (https://doi.org/10.1016/j. exger.2009.05.009)

66 Goto H, Osaki M, Fukushima T, Sakamoto K, Hozumi A, Baba H \& Shindo H. Human bone marrow adipocytes support dexamethasoneinduced osteoclast differentiation and function through RANKL expression. Biomedical Research 201132 37-44.

67 Fan Y, Hanai JI, Le PT, Bi R, Maridas D, DeMambro V, Figueroa CA, Kir S, Zhou X, Mannstadt M et al. Parathyroid hormone directs bone marrow mesenchymal cell fate. Cell Metabolism 201725 661-672. (https://doi.org/10.1016/j.cmet.2017.01.001)

68 Wang D, Haile A \& Jones LC. Dexamethasone-induced lipolysis increases the adverse effect of adipocytes on osteoblasts using cells derived from human mesenchymal stem cells. Bone 201353 520-530. (https://doi.org/10.1016/j.bone.2013.01.009)

69 Abdallah BM. Marrow adipocytes inhibit the differentiation of mesenchymal stem cells into osteoblasts via suppressing BMPsignaling. Journal of Biomedical Science 201724 11. (https://doi. org/10.1186/s12929-017-0321-4)

70 Liu LF, Shen WJ, Zhang ZH, Wang LJ \& Kraemer FB. Adipocytes decrease Runx2 expression in osteoblastic cells: roles of PPAR $\gamma$ and adiponectin. Journal of Cellular Physiology 2010225 837-845. (https://doi.org/10.1002/jcp.22291)

71 Stechschulte LA, Ge C, Hinds TD, Sanchez ER, Franceschi RT \& Lecka-Czernik B. Protein phosphatase PP5 controls bone mass and the negative effects of rosiglitazone on bone through reciprocal regulation of PPAR $\gamma$ (peroxisome proliferator-activated receptor $\gamma$ ) and RUNX2 (runt-related transcription factor 2). Journal of Biological Chemistry 2016291 24475-24486. (https://doi.org/10.1074/jbc. M116.752493)

72 Kato M, Patel MS, Levasseur R, Lobov I, Chang BHJ, Glass DA, Hartmann C, Li L, Hwang TH, Brayton CF et al. Cbfa1-independent decrease in osteoblast proliferation, osteopenia, and persistent embryonic eye vascularization in mice deficient in Lrp5, a Wnt coreceptor. Journal of Cell Biology 2002157 303-314. (https://doi. org/10.1083/jcb.200201089)

73 Taipaleenmäki H, Abdallah BM, AlDahmash A, Säämänen AM \& Kassem M. Wnt signalling mediates the cross-talk between bone marrow derived pre-adipocytic and pre-osteoblastic cell populations. Experimental Cell Research 2011317 745-756. (https://doi. org/10.1016/j.yexcr.2010.12.015)

74 Ross SE, Hemati N, Longo KA, Bennett CN, Lucas PC, Erickson RL \& MacDougald OA. Inhibition of adipogenesis by Wnt signaling. Science 2000289 950-953.

75 Logan CY \& Nusse R. The Wnt signaling pathway in development and disease. Annual Review of Cell and Developmental Biology 200420 781-810. (https://doi.org/10.1146/annurev. cellbio.20.010403.113126)

76 Etheridge SL, Spencer GJ, Heath DJ \& Genever PG. Expression profiling and functional analysis of wnt signaling mechanisms in mesenchymal stem cells. Stem Cells 200422 849-860. (https://doi. org/10.1634/stemcells.22-5-849)

77 Wang FS, Ko JY, Yeh DW, Ke HC \& Wu HL. Modulation of Dickkopf-1 attenuates glucocorticoid induction of osteoblast apoptosis, adipocytic differentiation, and bone mass loss. Endocrinology 2008 149 1793-1801. (https://doi.org/10.1210/en.2007-0910)

78 Poole KES, Bezooijen RL van, Loveridge N, Hamersma $\mathrm{H}$, Papapoulos SE, Löwik CW \& Reeve J. Sclerostin is a delayed secreted product of osteocytes that inhibits bone formation. FASEB Journal 200519 1842-1844. (https://doi.org/10.1096/fj.05-4221fje)

79 Cook DA, Fellgett SW, Pownall ME, O'Shea PJ \& Genever PG. Wntdependent osteogenic commitment of bone marrow stromal cells using a novel GSK3 $\beta$ inhibitor. Stem Cell Research 201412 415-427. (https://doi.org/10.1016/j.scr.2013.10.002)

80 Gong Y, Slee RB, Fukai N, Rawadi G, Roman-Roman S, Reginato AM, Wang H, Cundy T, Glorieux FH, Lev D et al. OsteoporosisPseudoglioma Syndrome Collaborative Group. LDL receptor-related protein 5 (LRP5) affects bone accrual and eye development. Cell 2001 107 513-523.

$81 \mathrm{Hu} \mathrm{H}$, Hilton MJ, Tu X, Yu K, Ornitz DM \& Long F. Sequential roles of Hedgehog and Wnt signaling in osteoblast development. Development 2005132 49-60. (https://doi.org/10.1242/dev.01564)

82 Cawthorn WP, Bree AJ, Yao Y, Du B, Hemati N, MartinezSantibañez G \& MacDougald OA. Wnt6, Wnt10a and Wnt10b inhibit adipogenesis and stimulate osteoblastogenesis through a $\beta$-catenin-dependent mechanism. Bone 201250 477-489. (https:// doi.org/10.1016/j.bone.2011.08.010)

83 Fairfield H, Falank C, Harris E, Demambro V, McDonald M, Pettit JA, Mohanty ST, Croucher P, Kramer I, Kneissel M et al. The skeletal cellderived molecule sclerostin drives bone marrow adipogenesis. Journal of Cellular Physiology 2018233 1156-1167. (https://doi.org/10.1002/ jcp.25976)

84 Bodine PVN, Zhao W, Kharode YP, Bex FJ, Lambert AJ, Goad MB, Gaur T, Stein GS, Lian JB \& Komm BS. The Wnt antagonist secreted frizzled-related protein-1 is a negative regulator of trabecular bone formation in adult mice. Molecular Endocrinology 200418 1222-1237. (https://doi.org/10.1210/me.2003-0498)

85 Nakanishi R, Akiyama H, Kimura H, Otsuki B, Shimizu M, Tsuboyama T \& Nakamura T. Osteoblast-targeted expression of Sfrp4 in mice results in low bone mass. Journal of Bone and Mineral Research 200823 271-277. (https://doi.org/10.1359/jbmr.071007)

86 Li X, Ominsky MS, Niu QT, Sun N, Daugherty B, D'Agostin D, Kurahara C, Gao Y, Cao J, Gong J, Asuncion F, Barrero M et al. 
Targeted deletion of the sclerostin gene in mice results in increased bone formation and bone strength. Journal of Bone and Mineral Research 200823 860-869. (https://doi.org/10.1359/jbmr.080216)

87 Yu C, Xuan M, Zhang M, Yao Q, Zhang K, Zhang X, Guo J \& Song L. Postnatal deletion of $\beta$-catenin in osterix-expressing cells is necessary for bone growth and intermittent PTH-induced bone gain. Journal of Bone and Mineral Metabolism 2017. (https://doi.org/10.1007/s00774017-0873-0)

88 Cawthorn WP, Scheller EL, Learman BS, Parlee SD, Simon BR, Mori H, Ning X, Bree AJ, Schell B, Broome DT et al. Bone marrow adipose tissue is an endocrine organ that contributes to increased circulating adiponectin during caloric restriction. Cell Metabolism 201420 368-375. (https://doi.org/10.1016/j.cmet.2014.06.003)

89 Kobayashi Y, Uehara S, Koide M \& Takahashi N. The regulation of osteoclast differentiation by Wnt signals. BoneKEy Reports 20154 713. (https://doi.org/10.1038/bonekey.2015.82)

90 Mishina Y, Starbuck MW, Gentile MA, Fukuda T, Kasparcova V, Seedor JG, Hanks MC, Amling M, Pinero GJ, Harada S et al. Bone morphogenetic protein type IA receptor signaling regulates postnatal osteoblast function and bone remodeling. Journal of Biological Chemistry 2004279 27560-27566. (https://doi.org/10.1074/jbc. M404222200)

91 Zhang F, Qiu T, Wu X, Wan C, Shi W, Wang Y, Chen JG, Wan M, Clemens TL \& Cao X. Sustained BMP signaling in osteoblasts stimulates bone formation by promoting angiogenesis and osteoblast differentiation. Journal of Bone and Mineral Research 200924 1224-1233. (https://doi.org/10.1359/jbmr.090204)

92 Phimphilai M, Zhao Z, Boules H, Roca H \& Franceschi RT. BMP signaling is required for RUNX2-dependent induction of the osteoblast phenotype. Journal of Bone and Mineral Research 200621 637-646. (https://doi.org/10.1359/jbmr.060109)

93 Zhao M, Qiao M, Harris SE, Chen D, Oyajobi BO \& Mundy GR. The zinc finger transcription factor Gli2 mediates bone morphogenetic protein 2 expression in osteoblasts in response to hedgehog signaling. Molecular and Cellular Biology 200626 6197-6208. (https:// doi.org/10.1128/MCB.02214-05)

94 Nohe A, Keating E, Knaus P \& Petersen NO. Signal transduction of bone morphogenetic protein receptors. Cellular Signalling 200416 291-299.

95 Kang Q, Song WX, Luo Q, Tang N, Luo J, Luo X, Chen J, Bi Y, He BC, Park JK et al. A comprehensive analysis of the dual roles of BMPs in regulating adipogenic and osteogenic differentiation of mesenchymal progenitor cells. Stem Cells and Development 200918 545-559. (https://doi.org/10.1089/scd.2008.0130)

96 Wang EA, Israel DI, Kelly S \& Luxenberg DP. Bone morphogenetic protein-2 causes commitment and differentiation in C3H10T1/2 and 3T3 cells. Growth Factors 19939 57-71.

97 Chen D, Ji X, Harris MA, Feng JQ, Karsenty G, Celeste AJ, Rosen V, Mundy GR \& Harris SE. Differential roles for bone morphogenetic protein (BMP) receptor type IB and IA in differentiation and specification of mesenchymal precursor cells to osteoblast and adipocyte lineages. Journal of Cell Biology $1998 \mathbf{1 4 2}$ 295-305.

98 Okazaki R, Inoue D, Shibata M, Saika M, Kido S, Ooka H, Tomiyama H, Sakamoto Y \& Matsumoto T. Estrogen promotes early osteoblast differentiation and inhibits adipocyte differentiation in mouse bone marrow stromal cell lines that express estrogen receptor (ER) alpha or beta. Endocrinology 2002143 2349-2356. (https://doi. org/10.1210/endo.143.6.8854)

99 Marcellini S, Henriquez JP \& Bertin A. Control of osteogenesis by the canonical Wnt and BMP pathways in vivo: cooperation and antagonism between the canonical Wnt and BMP pathways as cells differentiate from osteochondroprogenitors to osteoblasts and osteocytes. BioEssays 201234 953-962. (https://doi.org/10.1002/ bies.201200061)

100 Kamiya N, Ye L, Kobayashi T, Mochida Y, Yamauchi M, Kronenberg HM, Feng JQ \& Mishina Y. BMP signaling negatively regulates bone mass through sclerostin by inhibiting the canonical Wnt pathway. Development 2008135 3801-3811. (https://doi. org/10.1242/dev.025825)

101 Tsuji K, Bandyopadhyay A, Harfe BD, Cox K, Kakar S, Gerstenfeld L, Einhorn T, Tabin CJ \& Rosen V. BMP2 activity, although dispensable for bone formation, is required for the initiation of fracture healing. Nature Genetics 200638 1424-1429. (https://doi.org/10.1038/ ng1916)

102 Gazzerro E, Pereira RC, Jorgetti V, Olson S, Economides AN \& Canalis E. Skeletal overexpression of gremlin impairs bone formation and causes osteopenia. Endocrinology 2005146 655-665. (https://doi. org/10.1210/en.2004-0766)

103 Spinella-Jaegle S, Rawadi G, Kawai S, Gallea S, Faucheu C, Mollat P, Courtois B, Bergaud B, Ramez V, Blanchet AM et al. Sonic hedgehog increases the commitment of pluripotent mesenchymal cells into the osteoblastic lineage and abolishes adipocytic differentiation. Journal of Cell Science 2001114 2085-2094.

104 Fontaine C, Cousin W, Plaisant M, Dani C \& Peraldi P. Hedgehog signaling alters adipocyte maturation of human mesenchymal stem cells. Stem Cells 200826 1037-1046. (https://doi.org/10.1634/ stemcells.2007-0974)

105 Long MW, Robinson JA, Ashcraft EA \& Mann KG. Regulation of human bone marrow-derived osteoprogenitor cells by osteogenic growth factors. Journal of Clinical Investigation 199595 881-887. (https://doi.org/10.1172/JCI117738)

106 Okada A, Yamasaki S, Koga T, Kawashiri SY, Tamai M, Origuchi T, Nakamura H, Eguchi K \& Kawakami A. Adipogenesis of the mesenchymal stromal cells and bone oedema in rheumatoid arthritis. Clinical and Experimental Rheumatology 201230 332-337.

107 Naganawa T, Xiao L, Abogunde E, Sobue T, Kalajzic I, Sabbieti M, Agas D \& Hurley MM. In vivo and in vitro comparison of the effects of FGF-2 null and haplo-insufficiency on bone formation in mice. Biochemical and Biophysical Research Communications 2006339 490-498. (https://doi.org/10.1016/j.bbrc.2005.10.215)

108 Xiao L, Sobue T, Esliger A, Kronenberg MS, Coffin JD, Doetschman T \& Hurley MM. Disruption of the Fgf2 gene activates the adipogenic and suppresses the osteogenic program in mesenchymal marrow stromal stem cells. Bone 201047 360-370. (https://doi.org/10.1016/j. bone.2010.05.021)

109 Walker EC, McGregor NE, Poulton IJ, Solano M, Pompolo S, Fernandes TJ, Constable MJ, Nicholson GC, Zhang JG, Nicola NA et al. Oncostatin M promotes bone formation independently of resorption when signaling through leukemia inhibitory factor receptor in mice. Journal of Clinical Investigation 2010120 582-592. (https://doi.org/10.1172/JCI40568)

110 Takeuchi Y, Watanabe S, Ishii G, Takeda S, Nakayama K, Fukumoto S, Kaneta Y, Inoue D, Matsumoto T, Harigaya K et al. Interleukin-11 as a stimulatory factor for bone formation prevents bone loss with advancing age in mice. Journal of Biological Chemistry 2002277 49011-49018. (https://doi.org/10.1074/jbc.M207804200)

111 Kodama Y, Takeuchi Y, Suzawa M, Fukumoto S, Murayama H, Yamato H, Fujita T, Kurokawa T \& Matsumoto T. Reduced expression of interleukin-11 in bone marrow stromal cells of senescenceaccelerated mice (SAMP6): relationship to osteopenia with enhanced adipogenesis. Journal of Bone and Mineral Research 199813 1370-1377. (https://doi.org/10.1359/jbmr.1998.13.9.1370)

112 Osta B, Benedetti G \& Miossec P. Classical and paradoxical effects of TNF- $\alpha$ on bone homeostasis. Frontiers in Immunology 2014548. (https://doi.org/10.3389/fimmu.2014.00048)

113 Lu M, Xia L, Liu YC, Hochman T, Bizzari L, Aruch D, Lew J, Weinberg R, Goldberg JD \& Hoffman R. Lipocalin produced by myelofibrosis cells affects the fate of both hematopoietic and marrow microenvironmental cells. Blood 2015126 972-982. (https://doi. org/10.1182/blood-2014-12-618595)

114 Abdallah BM, Jafari A, Zaher W, Qiu W \& Kassem M. Skeletal (stromal) stem cells: an update on intracellular signaling pathways 
controlling osteoblast differentiation. Bone 201570 28-36. (https:// doi.org/10.1016/j.bone.2014.07.028)

115 Muruganandan S, Roman AA \& Sinal CJ. Role of chemerin/CMKLR1 signaling in adipogenesis and osteoblastogenesis of bone marrow stem cells. Journal of Bone and Mineral Research 201025 222-234. (https://doi.org/10.1359/jbmr.091106)

116 Poloni A, Maurizi G, Serrani F, Mancini S, Zingaretti MC, Frontini A, Cinti S, Olivieri A \& Leoni P. Molecular and functional characterization of human bone marrow adipocytes. Experimental Hematology 201341 558-566.e2. (https://doi.org/10.1016/j. exphem.2013.02.005)

117 Almeida M, Laurent MR, Dubois V, Claessens F, O’Brien CA, Bouillon R, Vanderschueren D \& Manolagas SC. Estrogens and androgens in skeletal physiology and pathophysiology. Physiological Reviews 201797 135-187. (https://doi.org/10.1152/ physrev.00033.2015)

118 Khosla S \& Monroe DG. Regulation of bone metabolism by sex steroids. Cold Spring Harbor Perspectives in Medicine 20188 a031211. (https://doi.org/10.1101/cshperspect.a031211)

119 Sharp JC, Copps JC, Liu Q, Ryner LN, Sebastian RA, Zeng GQ, Smith S, Niere JO, Tomanek B \& Sato M. Analysis of ovariectomy and estrogen effects on body composition in rats by X-ray and magnetic resonance imaging techniques. Journal of Bone and Mineral Research 200015 138-146. (https://doi.org/10.1359/jbmr.2000.15.1.138)

120 Li GW, Xu Z, Chang SX, Zhou L, Wang XY, Nian H \& Shi X. Influence of early zoledronic acid administration on bone marrow fat in ovariectomized rats. Endocrinology 2014155 4731-4738. (https:// doi.org/10.1210/en.2014-1359)

121 Tanizawa T, Yamaguchi A, Uchiyama Y, Miyaura C, Ikeda T, Ejiri S, Nagal Y, Yamato H, Murayama H, Sato M et al. Reduction in bone formation and elevated bone resorption in ovariectomized rats with special reference to acute inflammation. Bone 200026 43-53.

122 Martin RB \& Zissimos SL. Relationships between marrow fat and bone turnover in ovariectomized and intact rats. Bone 199112 123-131.

123 Wáng YXJ, Griffith JF, Deng M, Yeung DKW \& Yuan J. Rapid increase in marrow fat content and decrease in marrow perfusion in lumbar vertebra following bilateral oophorectomy: an MR imaging-based prospective longitudinal study. Korean Journal of Radiology 201516 154-159. (https://doi.org/10.3348/kjr.2015.16.1.154)

124 Dang ZC, Bezooijen RL van, Karperien M, Papapoulos SE \& Löwik CWGM. Exposure of KS483 cells to estrogen enhances osteogenesis and inhibits adipogenesis. Journal of Bone and Mineral Research 200217 394-405. (https://doi.org/10.1359/ jbmr.2002.17.3.394)

125 Zhao JW, Gao ZL, Mei H, Li YL \& Wang Y. Differentiation of human mesenchymal stem cells: the potential mechanism for estrogeninduced preferential osteoblast versus adipocyte differentiation. American Journal of the Medical Sciences 2011341 460-468. (https:// doi.org/10.1097/MAJ.0b013e31820865d5)

126 McCarthy TL, Kallen CB \& Centrella M. $\beta$-Catenin independent cross-control between the estradiol and Wnt pathways in osteoblasts. Gene 2011479 16-28. (https://doi.org/10.1016/j.gene.2011.02.002)

127 Matsumoto Y, Otsuka F, Takano-Narazaki M, Katsuyama T, Nakamura E, Tsukamoto N, Inagaki K, Sada KE \& Makino H. Estrogen facilitates osteoblast differentiation by upregulating bone morphogenetic protein-4 signaling. Steroids $2013 \mathbf{7 8}$ 513-520. (https://doi.org/10.1016/j.steroids.2013.02.011)

128 Wend K, Wend P, Drew BG, Hevener AL, Miranda-Carboni GA \& Krum SA. ERo regulates lipid metabolism in bone through ATGL and perilipin. Journal of Cellular Biochemistry 2013114 1306-1314. (https://doi.org/10.1002/jcb.24470)

129 Pedram A, Razandi M, Blumberg B \& Levin ER. Membrane and nuclear estrogen receptor $\alpha$ collaborate to suppress adipogenesis but not triglyceride content. FASEB Journal 201530 230-240. (https:// doi.org/10.1096/fj.15-274878)
130 Elbaz A, Rivas D \& Duque G. Effect of estrogens on bone marrow adipogenesis and Sirt1 in aging C57BL/6J mice. Biogerontology 2009 10 747-755. (https://doi.org/10.1007/s10522-009-9221-7)

131 Syed FA, Oursler MJ, Hefferan TE, Peterson JM, Riggs BL \& Khosla S. Effects of estrogen therapy on bone marrow adipocytes in postmenopausal osteoporotic women. Osteoporosis International 2008 19 1323-1330. (https://doi.org/10.1007/s00198-008-0574-6)

132 Limonard EJ, Veldhuis-Vlug AG, Dussen L van, Runge JH, Tanck MW, Endert E, Heijboer AC, Fliers E, Hollak CE, Akkerman EM et al. Shortterm effect of estrogen on human bone marrow fat. Journal of Bone and Mineral Research 201530 2058-2066. (https://doi.org/10.1002/ jbmr.2557)

133 Mirza F \& Canalis E. Management of endocrine disease: secondary osteoporosis: pathophysiology and management. European Journal of Endocrinology 2015173 R131-R151. (https://doi.org/10.1530/EJE-150118)

134 Justesen J, Mosekilde L, Holmes M, Stenderup K, Gasser J, Mullins JJ, Seckl JR \& Kassem M. Mice deficient in 11beta-hydroxysteroid dehydrogenase type 1 lack bone marrow adipocytes, but maintain normal bone formation. Endocrinology 2004145 1916-1925. (https:// doi.org/10.1210/en.2003-1427)

135 Cárcamo-Orive I, Gaztelumendi A, Delgado J, Tejados N, Dorronsoro A, Fernández-Rueda J, Pennington DJ \& Trigueros C. Regulation of human bone marrow stromal cell proliferation and differentiation capacity by glucocorticoid receptor and AP-1 crosstalk. Journal of Bone and Mineral Research 201025 2115-2125. (https://doi.org/10.1002/jbmr.120)

136 Komori T. Glucocorticoid Signaling and Bone Biology. Hormone and Metabolic Research 201648 755-763. (https://doi org/10.1055/s-0042-110571)

137 Wang FS, Ko JY, Weng LH, Yeh DW, Ke HJ \& Wu SL. Inhibition of glycogen synthase kinase-3beta attenuates glucocorticoid-induced bone loss. Life Sciences 200985 685-692. (https://doi.org/10.1016/j. lfs.2009.09.009)

138 Ghali O, Broux O, Falgayrac G, Haren N, Leeuwen JPTM van, Penel G, Hardouin P \& Chauveau C. Dexamethasone in osteogenic medium strongly induces adipocyte differentiation of mouse bone marrow stromal cells and increases osteoblast differentiation. BMC Cell Biology 201516 9. (https://doi.org/10.1186/s12860-0150056-6)

139 Li J, Zhang N, Huang X, Xu J, Fernandes JC, Dai K \& Zhang X. Dexamethasone shifts bone marrow stromal cells from osteoblasts to adipocytes by C/EBPalpha promoter methylation. Cell Death and Disease 20134 e832. (https://doi.org/10.1038/cddis.2013.348)

140 Zhang Y, Ma C, Liu X, Wu Z, Yan P, Ma N, Fan Q \& Zhao Q. Epigenetic landscape in PPAR $\gamma 2$ in the enhancement of adipogenesis of mouse osteoporotic bone marrow stromal cell. Biochimica et Biophysica Acta 20151852 2504-2516. (https://doi.org/10.1016/j. bbadis.2015.08.020)

141 Uchihashi K, Aoki S, Shigematsu M, Kamochi N, Sonoda E, Soejima H, Fukudome K, Sugihara H, Hotokebuchi T \& Toda S. Organotypic culture of human bone marrow adipose tissue. Pathology International 201060 259-267. (https://doi.org/10.1111/j.14401827.2010.02511.x)

142 Silva BC \& Bilezikian JP. Parathyroid hormone: anabolic and catabolic actions on the skeleton. Current Opinion in Pharmacology 201522 41-50. (https://doi.org/10.1016/j.coph.2015.03.005)

143 Yu B, Zhao X, Yang C, Crane J, Xian L, Lu W, Wan M \& Cao X. Parathyroid hormone induces differentiation of mesenchymal stromal/stem cells by enhancing bone morphogenetic protein signaling. Journal of Bone and Mineral Research 201227 2001-2014. (https://doi.org/10.1002/jbmr.1663)

144 Li C, Xing Q, Yu B, Xie H, Wang W, Shi C, Crane JL, Cao X \& Wan M. Disruption of LRP6 in osteoblasts blunts the bone anabolic activity of PTH. Journal of Bone and Mineral Research 201328 2094-2108. (https://doi.org/10.1002/jbmr.1962) 
145 Kim SW, Pajevic PD, Selig M, Barry KJ, Yang JY, Shin CS, Baek WY, Kim JE \& Kronenberg HM. Intermittent PTH administration converts quiescent lining cells to active osteoblasts. Journal of Bone and Mineral Research 201227 2075-2084. (https://doi.org/10.1002/jbmr.1665)

146 Balani DH, Ono N \& Kronenberg HM. Parathyroid hormone regulates fates of murine osteoblast precursors in vivo. Journal of Clinical Investigation 2017127 3327-3338. (https://doi.org/10.1172/ JCI91699)

147 Rickard DJ, Wang FL, Rodriguez-Rojas AM, Wu Z, Trice WJ, Hoffman SJ, Votta B, Stroup GB, Kumar S \& Nuttall ME. Intermittent treatment with parathyroid hormone (PTH) as well as a non-peptide small molecule agonist of the PTH1 receptor inhibits adipocyte differentiation in human bone marrow stromal cells. Bone 200639 1361-1372. (https://doi.org/10.1016/j.bone.2006.06.010)

148 Kulkarni NH, Wei T, Kumar A, Dow ER, Stewart TR, Shou J, N'cho M, Sterchi DL, Gitter BD, Higgs RE et al. Changes in osteoblast, chondrocyte, and adipocyte lineages mediate the bone anabolic actions of PTH and small molecule GSK-3 inhibitor. Journal of Cellular Biochemistry 2007102 1504-1518. (https://doi.org/10.1002/ jcb.21374)

149 Yang Y, Luo X, Xie X, Yan F, Chen G, Zhao W, Jiang Z, Fang C $\&$ Shen J. Influences of teriparatide administration on marrow fat content in postmenopausal osteopenic women using MR spectroscopy. Climacteric 201619 285-291. (https://doi.org/10.3109/ 13697137.2015.1126576)

150 Yakar S \& Isaksson O. Regulation of skeletal growth and mineral acquisition by the GH/IGF-1 axis: lessons from mouse models. Growth Hormone and IGF Research 201628 26-42. (https://doi. org/10.1016/j.ghir.2015.09.004)

151 Jia D \& Heersche JN. Insulin-like growth factor-1 and -2 stimulate osteoprogenitor proliferation and differentiation and adipocyte formation in cell populations derived from adult rat bone. Bone 2000 27 785-794.

152 Scavo LM, Karas M, Murray M \& Leroith D. Insulin-like growth factor-I stimulates both cell growth and lipogenesis during differentiation of human mesenchymal stem cells into adipocytes. Journal of Clinical Endocrinology and Metabolism 200489 3543-3553. (https://doi.org/10.1210/jc.2003-031682)

153 Menagh PJ, Turner RT, Jump DB, Wong CP, Lowry MB, Yakar S, Rosen CJ \& Iwaniec UT. Growth hormone regulates the balance between bone formation and bone marrow adiposity. Journal of Bone and Mineral Research 201025 757-768. (https://doi.org/10.1359/ jbmr.091015)

154 Kassem M, Blum W, Ristelli J, Mosekilde L \& Eriksen EF. Growth hormone stimulates proliferation and differentiation of normal human osteoblast-like cells in vitro. Calcified Tissue International 1993 52 222-226.

155 Gevers EF, Loveridge N \& Robinson ICAF. Bone marrow adipocytes: a neglected target tissue for growth hormone. Endocrinology $2002 \mathbf{1 4 3}$ 4065-4073. (https://doi.org/10.1210/en.2002-220428)

156 Appiagyei-Dankah Y, Tapiador CD, Evans JF, Castro-Magana M, Aloia JF \& Yeh JK. Influence of growth hormone on bone marrow adipogenesis in hypophysectomized rats. American Journal of Physiology: Endocrinology and Metabolism 2003284 E566-E573. (https://doi.org/10.1152/ajpendo.00213.2002)

157 Bredella MA, Gerweck AV, Barber LA, Breggia A, Rosen CJ, Torriani M \& Miller KK. Effects of growth hormone administration for 6 months on bone turnover and bone marrow fat in obese premenopausal women. Bone 201462 29-35. (https://doi.org/10.1016/j. bone.2014.01.022)

158 Turner RT, Kalra SP, Wong CP, Philbrick KA, Lindenmaier LB, Boghossian S \& Iwaniec UT. Peripheral leptin regulates bone formation. Journal of Bone and Mineral Research 201328 22-34. (https://doi.org/10.1002/jbmr.1734)

159 Philbrick KA, Wong CP, Branscum AJ, Turner RT \& Iwaniec UT. Leptin stimulates bone formation in ob/ob mice at doses having minimal impact on energy metabolism. Journal of Endocrinology 2017 232 461-474. (https://doi.org/10.1530/JOE-16-0484)

160 Yue R, Zhou BO, Shimada IS, Zhao Z \& Morrison SJ. Leptin receptor promotes adipogenesis and reduces osteogenesis by regulating mesenchymal stromal cells in adult bone marrow. Cell Stem Cell 2016 18 782-796. (https://doi.org/10.1016/j.stem.2016.02.015)

161 Chang YJ, Shih DT bi, Tseng CP, Hsieh TB, Lee DC \& Hwang SM. Disparate mesenchyme-lineage tendencies in mesenchymal stem cells from human bone marrow and umbilical cord blood. Stem Cells 200624 679-685. (https://doi.org/10.1634/stemcells.2004-0308)

162 Scheller EL, Song J, Dishowitz MI, Soki FN, Hankenson KD $\&$ Krebsbach PH. Leptin functions peripherally to regulate differentiation of mesenchymal progenitor cells. Stem Cells 201028 1071-1080. (https://doi.org/10.1002/stem.432)

163 Zhou BO, Yue R, Murphy MM, Peyer JG \& Morrison SJ. Leptinreceptor-expressing mesenchymal stromal cells represent the main source of bone formed by adult bone marrow. Cell Stem Cell 201415 154-168. (https://doi.org/10.1016/j.stem.2014.06.008)

164 Tanaka Y, Hasegawa T, Yamada T, Yamamoto T, Sasaki M, Hongo H, Tsuboi K, Haraguchi M, Freitas PHL de, Li M, Oda K et al. Histological assessment for femora of ovariectomized obesity $(\mathrm{db} / \mathrm{db})$ mice carrying mutated leptin receptor. Histology and Histopathology 2016 31 1315-1326. (https://doi.org/10.14670/HH-11-758)

165 Karsenty G. Convergence between bone and energy homeostases: leptin regulation of bone mass. Cell Metabolism 20064 341-348. (https://doi.org/10.1016/j.cmet.2006.10.008)

166 Hamrick MW, Pennington C, Newton D, Xie D \& Isales C. Leptin deficiency produces contrasting phenotypes in bones of the limb and spine. Bone 200434 376-383. (https://doi.org/10.1016/j. bone.2003.11.020)

167 Hamrick MW, Della-Fera MA, Choi YH, Pennington C, Hartzell D \& Baile CA. Leptin treatment induces loss of bone marrow adipocytes and increases bone formation in leptin-deficient ob/ob mice. Journal of Bone and Mineral Research 200520 994-1001. (https://doi. org/10.1359/JBMR.050103)

168 Martin A, Vittoris R de, David V, Moraes R, Bégeot M, LafageProust MH, Alexandre C, Vico L \& Thomas T. Leptin modulates both resorption and formation while preventing disuse-induced bone loss in tail-suspended female rats. Endocrinology 2005146 3652-3659. (https://doi.org/10.1210/en.2004-1509)

169 Devlin MJ, Brooks DJ, Conlon C, Vliet M van, Louis L, Rosen CJ \& Bouxsein ML. Daily leptin blunts marrow fat but does not impact bone mass in calorie-restricted mice. Journal of Endocrinology 2016 229 295-306. (https://doi.org/10.1530/JOE-15-0473)

170 Legroux-Gérot I, Vignau J, Viltart O, Hardouin P, Chauveau C $\&$ Cortet B. Adipokines and bone status in a cohort of anorexic patients. Joint Bone Spine 2018. (https://doi.org/10.1016/j. jbspin.2018.03.014)

171 Biver E, Salliot C, Combescure C, Gossec L, Hardouin P, Legroux-Gerot I \& Cortet B. Influence of adipokines and ghrelin on bone mineral density and fracture risk: a systematic review and meta-analysis. Journal of Clinical Endocrinology and Metabolism 2011 96 2703-2713. (https://doi.org/10.1210/jc.2011-0047)

172 Kanazawa I, Yamaguchi T, Yamamoto M, Yamauchi M, Yano S \& Sugimoto T. Relationships between serum adiponectin levels versus bone mineral density, bone metabolic markers, and vertebral fractures in type 2 diabetes mellitus. European Journal of Endocrinology 2009160 265-273. (https://doi.org/10.1530/EJE-08-0642)

173 Kajimura D, Lee HW, Riley KJ, Arteaga-Solis E, Ferron M, Zhou B, Clarke CJ, Hannun YA, DePinho RA, Guo XE et al. Adiponectin regulates bone mass via opposite central and peripheral mechanisms through FoxO1. Cell Metabolism 201317 901-915. (https://doi. org/10.1016/j.cmet.2013.04.009)

$174 \mathrm{Wu}$ Y, Tu Q, Valverde P, Zhang J, Murray D, Dong LQ, Cheng J, Jiang H, Rios M, Morgan E et al. Central adiponectin administration reveals new regulatory mechanisms of bone metabolism in mice. 
American Journal of Physiology: Endocrinology and Metabolism 2014306 E1418-E1430. (https://doi.org/10.1152/ajpendo.00048.2014)

175 Abbott MJ, Roth TM, Ho L, Wang L, O'Carroll D \& Nissenson RA. Negative skeletal effects of locally produced adiponectin. PLoS ONE 201510 e0134290. (https://doi.org/10.1371/journal.pone.0134290)

176 Yokota T, Meka CSR, Medina KL, Igarashi H, Comp PC, Takahashi M, Nishida M, Oritani K, Miyagawa JI, Funahashi T et al. Paracrine regulation of fat cell formation in bone marrow cultures via adiponectin and prostaglandins. Journal of Clinical Investigation 2002 109 1303-1310. (https://doi.org/10.1172/JCI14506)

177 Lee HW, Kim SY, Kim AY, Lee EJ, Choi JY \& Kim JB. Adiponectin stimulates osteoblast differentiation through induction of COX2 in mesenchymal progenitor cells. Stem Cells 200927 2254-2262. (https://doi.org/10.1002/stem.144)

178 Wei W, Dutchak PA, Wang X, Ding X, Wang X, Bookout AL, Goetz R, Mohammadi M, Gerard RD, Dechow PC et al. Fibroblast growth factor 21 promotes bone loss by potentiating the effects of peroxisome proliferator-activated receptor $\gamma$. PNAS 2012109 3143-3148. (https://doi.org/10.1073/pnas.1200797109)

179 Sui BD, Hu CH, Zheng CX \& Jin Y. Microenvironmental views on mesenchymal stem cell differentiation in aging. Journal of Dental Research 201695 1333-1340. (https://doi. org/10.1177/0022034516653589)

180 Rinotas V, Niti A, Dacquin R, Bonnet N, Stolina M, Han CY, Kostenuik P, Jurdic P, Ferrari S \& Douni E. Novel genetic models of osteoporosis by overexpression of human RANKL in transgenic mice. Journal of Bone and Mineral Research 201429 1158-1169. (https://doi. org/10.1002/jbmr.2112)

181 Duque G, Li W, Adams M, Xu S \& Phipps R. Effects of risedronate on bone marrow adipocytes in postmenopausal women. Osteoporosis International 201122 1547-1553. (https://doi.org/10.1007/s00198010-1353-8)

Received 6 March 2018

Revised version received 21 May 2018

Accepted 3 July 2018 